\title{
Constructing and Validating the Questionnaire of the Factors Influencing the Implementation of Green Productivity Strategy in Iran`s Sport
}

\author{
Ali Reza Ghalehnoei ${ }^{1}$, Hassan Fahimdavin ${ }^{2}$, Hossein Peymanizad ${ }^{3}$, Mohammad Reza Esmailzadeh ${ }^{4}$ \\ 1. Ali Reza Ghalehnoei, (Ph.D Student) Islamic Azad University, Mashhad Branch, Mashhad, Iran \\ 2. Hassan Fahimdavin, (Ph.D) Islamic Azad University, Mashhad Branch, Mashhad, Iran \\ 3. Hossein Peymanizad, (Ph.D) Islamic Azad University, Mashhad Branch, Mashhad, Iran \\ 4. Mohammad Reza Esmailzadeh, (Ph.D) Islamic Azad University, Mashhad Branch, Mashhad, Iran
}

\section{ARTICLE INFO}

Received November 2018

Accepted August 2019

\section{KEYWORDS:}

Validity

Reliability

CFA

Green Productivity Strategy

Sport

CITE:

Ghalehnoei, Fahimdavin, Peymanizad, Esmailzadeh, Constructing and Validating the Questionnaire of the Factors Influencing the Implementation of Green Productivity Strategy in Iran's Sport, Research in sport management \& motor behavior, 2020: 9(18):127-146

\section{ABSTRACT}

The aim of this research was to constructing and validating the questionnaire of the factors influencing the implementation of green productivity strategy in Iran's sport. The present research carried out in a combination (qualitative and quantitative) method. The statistical population of the research in the qualitative stage consisted of 20 environmental experts and sports management professors, and in a quantitative stage consisted of all sports managers, environmental experts and university professors. The sample size was determined by using purposeful judgment available sampling 357 people. Content and construct validity of the questionnaire was confirmed and its reliability coefficient was estimated to be 0.86 .The results of the research identified and introduced seven effective factors (education and research, human resources, culture and attitudes, laws and regulations, control and supervision, management and planning, and physical factors) as effective factors. These factors produced a questionnaire with 39 items that explained $61.77 \%$ of the variance of green productivity. Additionally, the fitness indices of the first and second order confirmatory factor analysis supported the structure of the questionnaire. The constructed tool has a functional capability as well as a good validity and reliability. As such, the tool is suggested to be used in the evaluation and management of green productivity of sports organizations. 


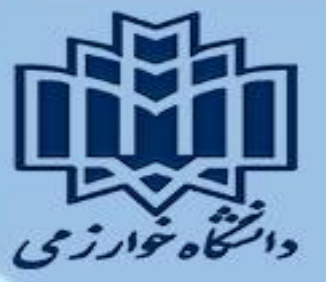

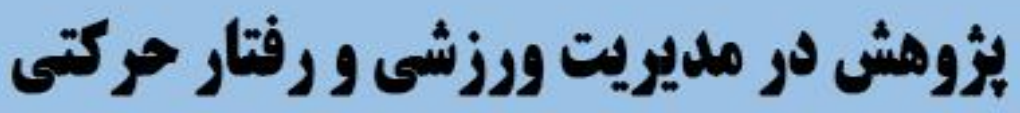

\section{ساخت و اعتباريابى يرسشنامه عوامل مؤثر در ياده سازى استراتزى بهره ورى سبز در ورزش ايران}

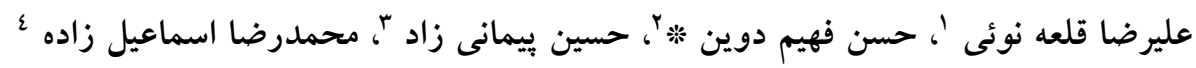

$$
\begin{aligned}
& \text { 1. دانشجوى دكترى مديريت ورزشى، دانشگاه آزاد اسلامى واحد مشهد، مشهد، ايران }
\end{aligned}
$$

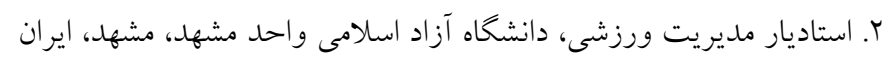

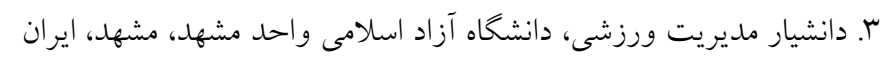

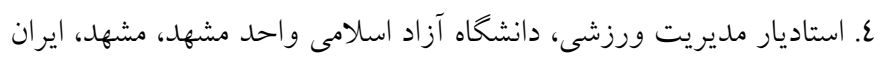

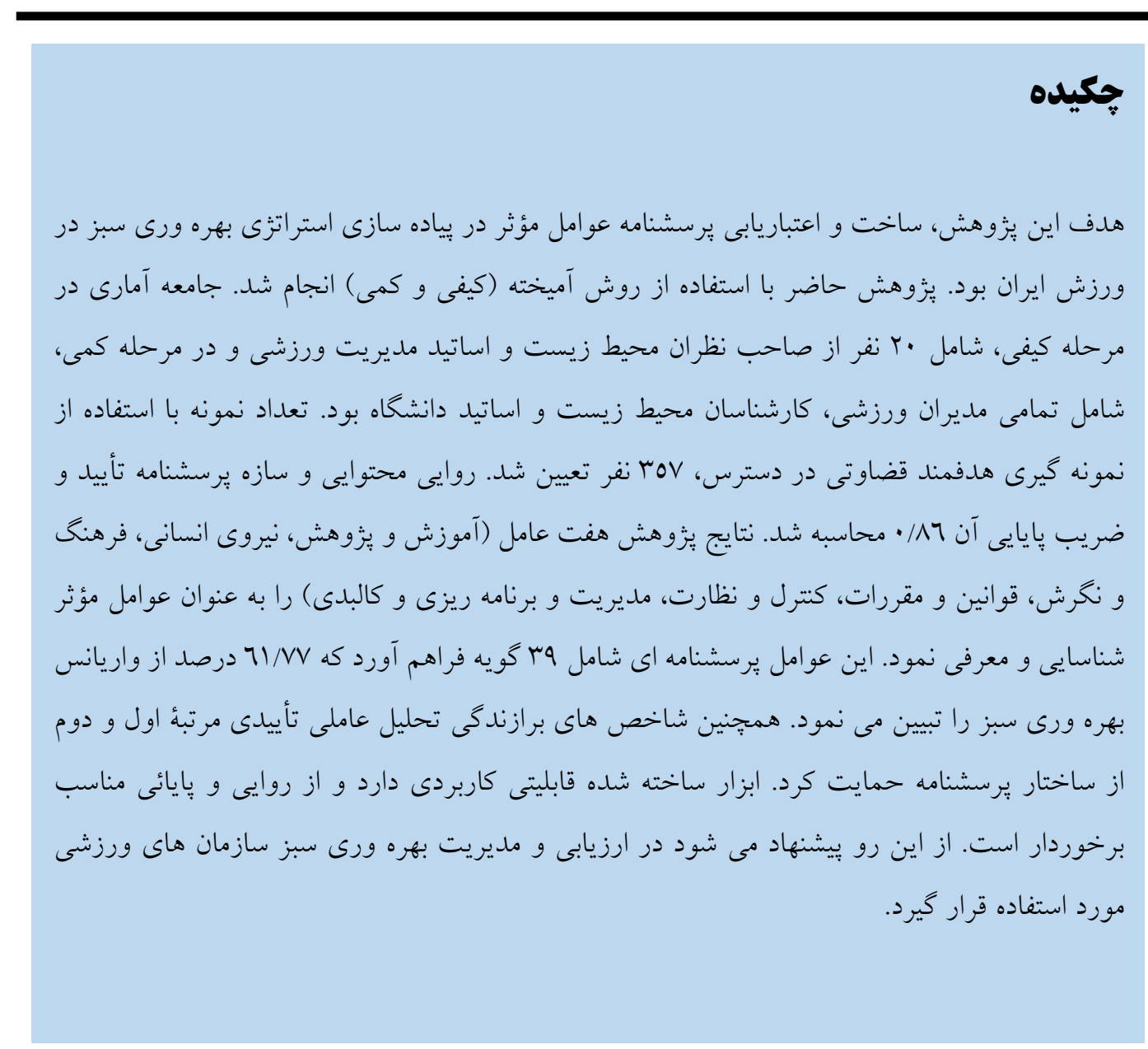

اطلاعات مقاله:

دريافت مقاله آبانVqrا

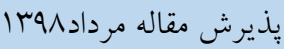

ث:ونويسنده مسئول:

fahim_pe@yahoo.com

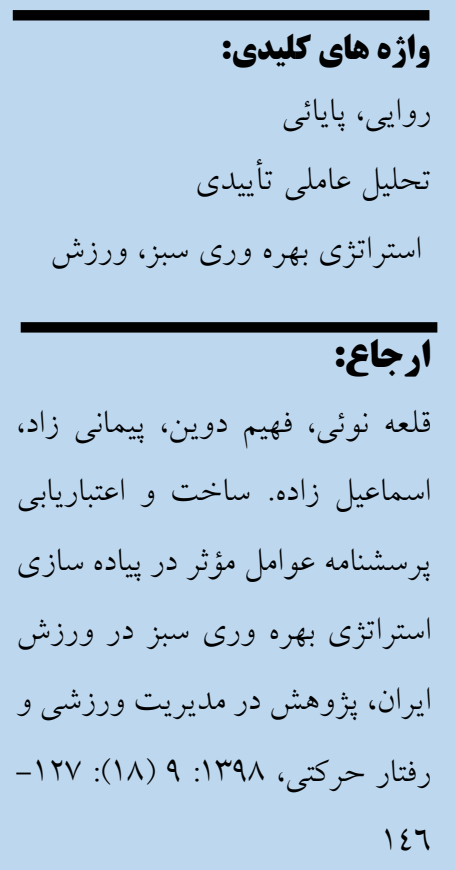

https://jrsm.khu.ac.ir/ 


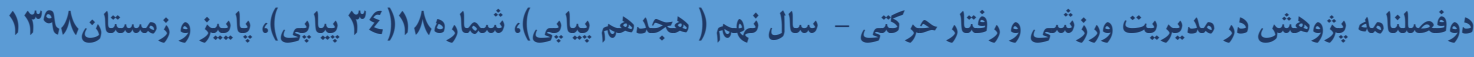

مقلهمه

مفهوم بهره ورى سبز ' در سال ع 199 توسط سازمان بهره ورى آسيا' معرفى گرديد. بهره ورى سبز استراتزى انتخاب شده اى براى توسعه بايدارّم محيطى است. هدف اصلى آن افزايش بهره ورى و توسعه اقتصادى-اجتماعى است به نحوى كه موجب حفاظت و ايمنى محيطى گردد ( (1). استراتزى بهره ورى سبز كاربرد روش ها، فناورى ها و سيستم هاى مديريتى خاص براى توليد كالاها و خدمات ساز گار با محيط زيست است (Y). متدولوزى آن از جندين بخش تشكيل شده و هر بخش داراى مراحل و كام هاى متعدد بوده كه نيازمند ابزارها، تكنيك ها و تكنولوزى هاى ويزه است (Y). در بهره ورى سبز (توسعه و محيط زيست)) دو روى يكى سكه هستند و اين بدان معناست كه هر استراتزى توسعه كه بخواهد بِيدار باشد، بايد بر روى كيفيت، سود آورى و محيط زيست تمركز نمايد و اين سه عامل (كيفيت، سود آورى و محيط زيست) سه ضلع مثلث بهره ورى سبز را تشكيل مى دهند (r). بهره ورى سبز در تمام بخش هاى خدماتى، كشاورزى و توليدى قابل بكار گيرى است (T). ورزش به عنوان يكى از بديدههاى جذاب و اثر كذار در بهبود جنبه هاى اجتماعى، اقتصادى و فرهنكى جامعه، از محور هاى اساسى دستيابى به توسعه بايدار بوده كه نيازمند توجه به اين استراتزى است. شناسايى عوامل اثر گذار در استراتزى بهره ورى سبز و طراحى ابزار سنجش آن يكى از مباحث كليدى و اصلى سازمان هاى ورزشى بوده و انجام تحقيق در اين باره يك ضرورت مى باشد. اكثر تحقيقات بهره ورى سبز در ايران و جهان، در صنايع و شركت هاى توليدى و خدماتى انجام شده است. برخى از آن ها به موانع و مشكلات بهره ورى سبز اشاره داثته و برخى به عوامل مؤثر در ارتقاء اين استراتزى برداخته اند. فلاح و همكاران (ع (1) جهار عامل عدم تعهل مديريت، عدم انتقال صحيح استراتزى، فقدان منابع كافى و عدم همسويى كاركنان را از جمله موانع بهره ورى سبز در سازمان مترو تهران ذكر

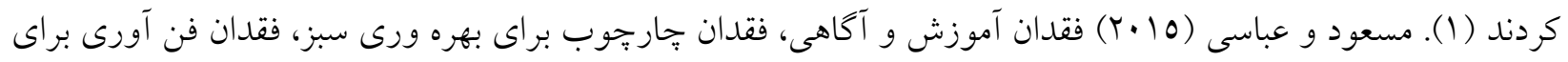
توليد و اجراى منابع جايخزين انرزى، علاقه دولت به راه حل هاى كوتاه مدت براى مشكل بحران انرزى، فقدان هماهنخى و همكارى دستخاه هاى دولتى را از موانع بهره ورى سبز در پِاكستان عنوان نمودند (ع). كامرال و شمس (Y.IV) فقدان قوانين مربوط به تداركات سبز، حمايت از مديريت ارشد سبز، انخيزه هاى دولت براى خريد سبز و عدم حمايت مالى را از مfم ترين جالش هاى موجود اجراى برنامه هاى سبز استراليا دانستند (0). زمانى (•وس (1) دو شاخص آناليز هزينهمنفعت و رضايت مندى يرسنل را به عنوان مهمترين عوامل اجرا نظام بهره ورى سبز در شركت ساييا معرفى كرد (7). حاج حسينى مهريزى و همكاران (•وس|) تخصص و مهارت، افزايش سطح مشاركت نيروى انسانى، هدف گذارى، تحقيق و توسعه مؤثر، رهبرى و انخيزش يرسنل را از راهكارهاى تحقق بهتر استراتزى بهره ورى سبز در صنايع نساجى دانستند

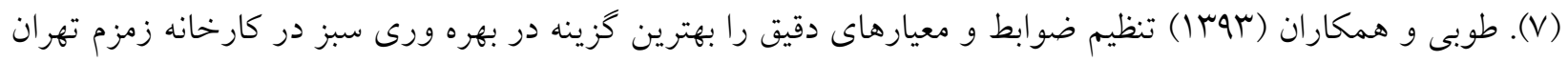
ذكر كردند (1). كاندهى و همكاران (10 +r) برخوردارى از مديريت فعال و بويا، لو كاموسو و سوهايزا (•(Y) كيفيت

\footnotetext{
1. Green Productivity

2. Asian Productivity Organization(APO)

3. Sustainable development
}

https://jrsm.khu.ac.ir/ 


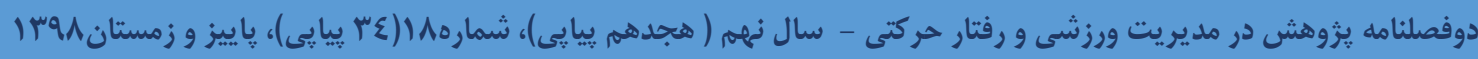

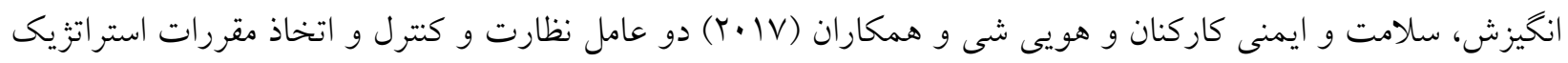
مبتنى بر بازار را از عوامل اصلى بهره ورى سبز عنوان نمودند (9، •1،11). در اين راستا باتوويتاج (10 (Y) بيشنهاد، يروزه معرفى و اشاعه بهره ورى سبز، برنامه آموزش مدرسان بهره ورى سبز و افزايش دسترسى به اساتيد متخصص را براى ارتقاى بهره ورى سبز در كشور سرى لانكا مطرح نمود (r (I). در حوزه تحقيقات ورزشى، فروغى بور و همكاران ( •و I ) عوامل نيروى انسانى، كالبدى، برنامه ريزى، مديريت، كنترل و نظارت، تعمير و نخهدارى و مالى را به عنوان عوامل اثر كذار

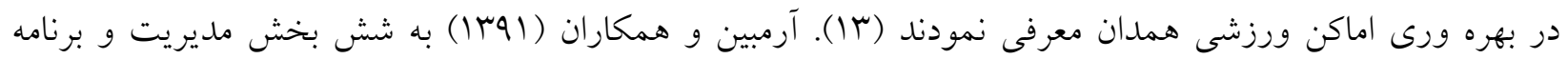
ريزى، نيروى انسانى، مشترى مدارى، نظارت و ارزيابى و بخش مالى به عنوان عوامل مهم در بهره ورى ورزش كرمان

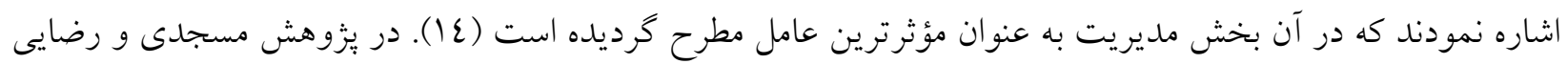
صوفى (90با() مؤلفه هاى كاربر، نظارت وكنترل، مديريت و برنامه ريزى، امكانات و تجهيزات فيزيكى، نيروى انسانى ماهر و بودجه و اعتبارات كافى، به ترتيب داراى بيشترين وزن بر افزايش بهره ورى اماكن و فضاهاى ورزشى شهردارى اصفهان بودند (10). درتحقيق راستخو و همكاران (1\%97) نيز اثر عوامل مديريتى، اقتصادى و محيطى، سازمانى و روانى بر بهره ورى نيروى انسانى در فدراسيون هاى ورزشى تأييد كرديد و عامل مديريتى در اولويت اول و عامل فردى در انتها قرار كرفت (17) كمبود سرانه فضاهاى ورزشى ، فاصله زياد سرانه فضاى ورزشى ايران با استاندارد جهانى، ضعف مديريت اماكن و فضاهاى ورزشى، اتكاء ورزش به اعتبارات مالى محدود دولت و كم توجهى به ملاحظات زيست محيطى در ورزش و نقش ارزنده بهره ورى سبز در اقتصاد ورزش، ضرورت برداختن به استراتزى ( بهرهورى سبز در ورزش) را بيش از بيش مورد تأكيد قرار مى دهد. برخوردارى كميته بين المللى المبيك از حق ميزبانى بازى هاى المبيك، افزايش سود آورى

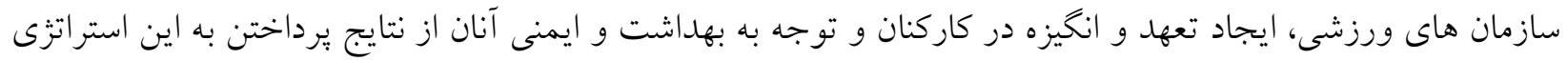
است. نظر به اين كه تاكنون يزوهشى در زمينه ساخت ابزار سنجش بهره ورى سبز در ورزش، در ايران و جهان انجام نشده است و يكى از مهم ترين عوامل در ارزشيابى بهره ورى سبز ارائه ابزار مناسب است، محقق بر آن شد با استفاده از

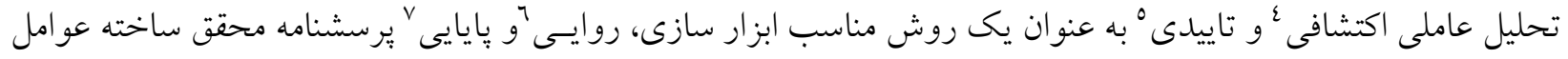
مؤثر در بهره ورى سبز را با در نظر كرفتن ويزّى ها و خصوصيات فرهنكى و اجتماعى محيط بزوهش، مورد سنجش قرار دهد. اميد است كه نتايج حاصل از اين تحقيق بتواند ابزارى مناسب براى سنجش عوامل مؤثر در بهره ورى سبز در ورزش در اختيار يزوهشخران قرار دهد.

\footnotetext{
4. Exploratory Factor Analyzing (EFA)

5. Confirmatory Factor Analyzing (CFA)

6 . Validity

7. Reliability
} 


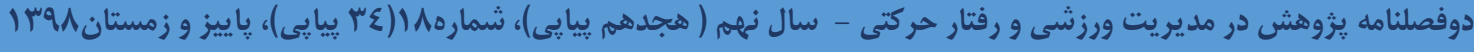

روش شناسى تحقيق

با توجه به ماهيت موضوع، تحقيق حاضر از نظر هدف از نوع تحقيقات كاربردى و از حيث ماهيت، اكتشافى و روش

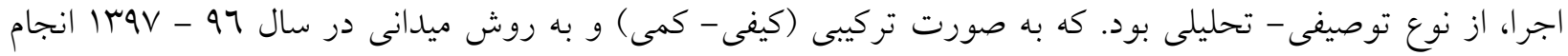
كرديد. موضوع يزوهش، ضرورت بهره كيرى از داده هاى كمى و كيفى را ايجاب نمود. در اين روش براى فهم بهتر موضوع و تبيين دقيق تر آن داده هاى كمى و كيفى با هم تر كيب مى شوند و شواهد بيشترى براى درى يديده فراهم مى آورند (IV). وقتى اين دو نوع داده يا يافته تركيب مى شوند، تصوير بسيار قدرتمندى از بديده مورد بررسى بدست مى آيد (1) إ). جامعه آمارى در بخش كيفى شامل •r نفر از صاحب نظران محيط زيست، سازمان ملى بهره ورى، كارشناسان توسعه و تجهيز نوسازى، مديران فدراسيون هاى ورزشى، كميته ملى المييك و اساتيد مديريت ورزشى دانشگاه بودند كه به شيوه هدفمند^ انتخاب و جهت شناسايى ابعاد و عوامل مؤثر (مؤلفه هاى) بهره ورى سبز در ورزش با آنان مصاحبه علمى شد. جامعه آمارى در بخش كمى شامل اساتيد مديريت ورزشى دانشخاه ها, معلمان (داراى مدرى دكترى تربيت بدنى و دانشجوى دكترى)، معاونان تربيت بدنى و سلامت وزارت آموزش و بِرورش و استان ها، مديران كل ورزش هان وجوانان، محيط زيست، توسعه و تجهيز نوسازى، مديران سازمان ملى بهره ورى، مديران كميته ملى المييك، رؤسا، دبيران و مديران فدراسيون هاى ورزشى بودند، كه با توجه به تنوع و عدم دسترسى كامل به جامعه آمارى و نامعلوم بودن تعداد

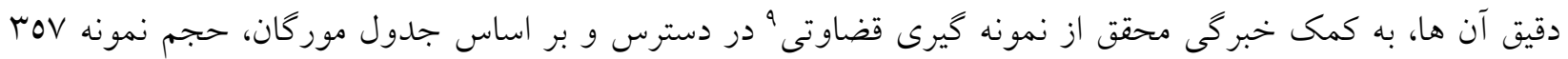
نفر انتخاب شد. براى گردآورى اطلاعات در مرحله كيفى از طريق مصاحبه نيمه ساختار يافته، داده ها جمع آورى و بعد

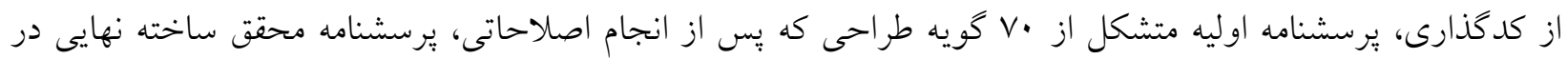
هفت مؤلفه و وب كويه (سؤال) براساس مقياس ينج ارزشى ليكرت (خيلى كم، كم، متوسط، زياد، خيلى زياد) تهيه كرديد. جهت امتياز دهى و ارزش كزارى كمى ياسخهاى سوالات مقياس، از طيف ليكرت 0 درجه استفاده شد. بخش اول يرسشنامه، مشخصات فردى (جنسيت، سن، مدرى تحصيلى، سابقه خدمت، محل اشتغال، يِت سازمانى) و بخش دوم آن شامل عوامل مؤثر بر اجراى استراتزى بهره ورى سبز در ورزش بود. محتويات آن شامل عوامل مديريت و برنامه ريزى

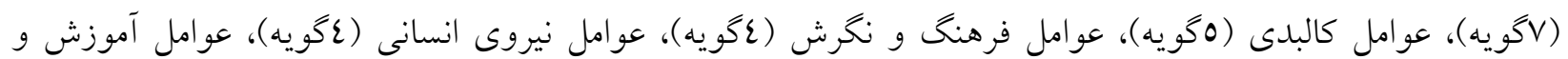

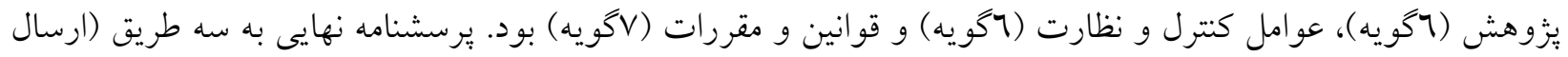

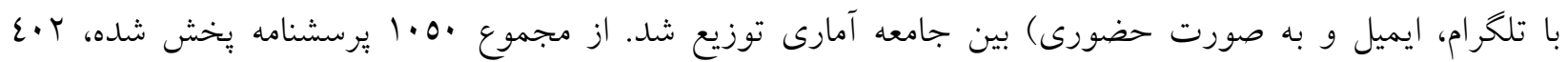

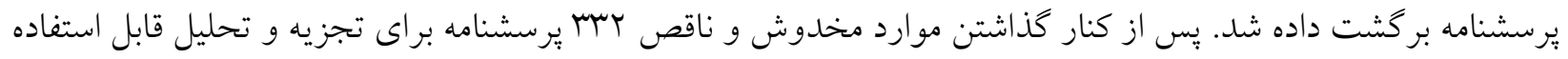

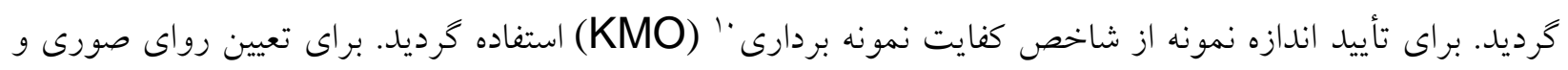

\footnotetext{
8. purposive

9 . judgmental

10. Kaiser-Meyer-Olkin (KMO)
}

https://jrsm.khu.ac.ir/ 


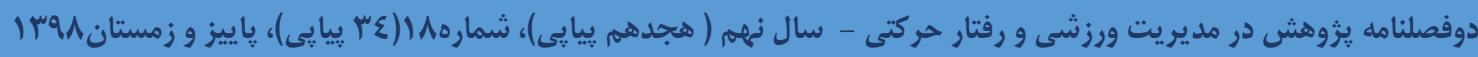

محتوايى يرسشنامه از بررسى دقيق متون و ادبيات تحقيق در مورد بهره ورى سبز و نهادينه كردن و دقت نظر ·r نفر از

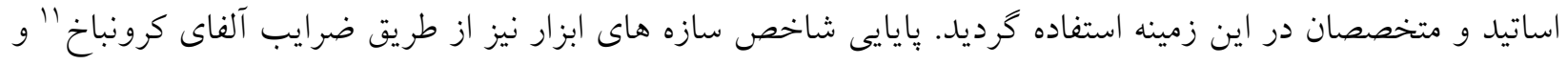

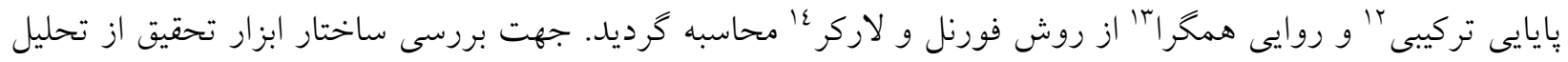

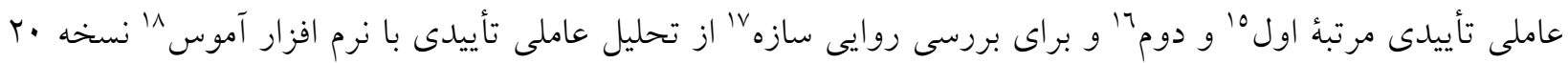
|ستفاده شد.

\section{يافته ها و نتايج تحقيق}

بررسى ويزگى هاى جمعيت شناختى نشان داد، Vo درصد نمونه ها در مرحله كيفى مرد بودند. همه آن ها بيش از 10 سال سابقهُ يزوهشى يا اجرايى مرتبط با موضوع تحقيق داشتند. •9 درصد مصاحبه شوند كان عضو هيئت علمى دانشخاه ها و مر اكز آموزش عالى و داراى مدرك دكترى و دانشجوى دكترى بوده و حوزهُ مطالعاتى و كارى آن ها مديريت ورزشى و محيط زيست بود. در بخش كمى نيز ويزگى هاى جمعيت شناختى نمونه ها مورد بررسى قرار كرفت. برخى از شاخص ها درجدول ا ارائه شده است.

جدول (. شاخص هاى جمعيت شناختى نمونه مورد مطالعه ( بخش كمى )

\begin{tabular}{|c|c|c|c|c|}
\hline درصد تجمعى & درصد & فراوانى & كروه & شاخص \\
\hline$V \varepsilon / 1$ & $V \varepsilon / 1$ & $r \varepsilon 7$ & مرد & \multirow[t]{2}{*}{ جنسيت } \\
\hline $1 \cdots$ & ro/9 & $\wedge 7$ & ز ت من & \\
\hline $0 / \varepsilon$ & $0 / \varepsilon$ & 11 & كارشناسى & \multirow{4}{*}{ تحصيزان } \\
\hline rN/ & $m / 1$ & 11. & كارشناسى ارشد & \\
\hline $79 / 99$ & $\mu / \mu$ & $1 \cdot \varepsilon$ & دانشجوى دكترى & \\
\hline $1 \cdots$ & $r \cdot / 1$ & $1 \cdots$ & دكترى & \\
\hline$r / \cdot$ & $r / \cdot$ & 1. & كميته ملى المييكى & \multirow{9}{*}{ سازمان } \\
\hline$\Lambda / V$ & $O / V$ & 19 & سازمان توسعه و تجهيز & \\
\hline $1 \pi / 9$ & $0 / 1$ & IV & سازمان محيط زيست & \\
\hline $17 /$ & $r / 1$ & $\mathrm{v}$ & سازمان ملى بهره ورى & \\
\hline$r q / r$ & $1 \mu / \mu$ & $\varepsilon \varepsilon$ & فدراسيون هاى ورزشى & \\
\hline$O V / T$ & $\mathrm{r \Lambda} / \cdot$ & $9 \pi$ & وزارت آموزش عالى & \\
\hline $1 Y / 0$ & ro/r & $\wedge \varepsilon$ & وزارت آموزش و يرورش & \\
\hline $90 / 1$ & $1 \mu / \mu$ & $\varepsilon \varepsilon$ & وزارت ورزش و جو انان & \\
\hline $1 \cdots$ & $\varepsilon / \tau$ & $1 \varepsilon$ & ساير ادارات & \\
\hline
\end{tabular}

\footnotetext{
11. Cronbach Alpha

12. Composite Reliability(CR)

13. Average Variance Extracted (AVE)

14. Fornell \& Larcker

15. First order factor analysis

16. Second order factor analysis

17. Construct validity

18. AMOS
} 


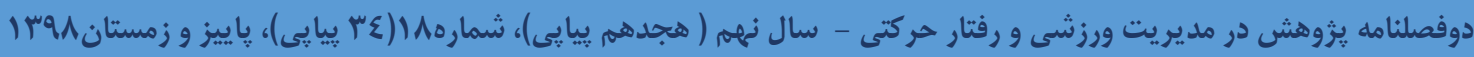

نتايج جدول ا نشان داد كه حدود Vo درصد شركت كنند كان در بزوهش، مرد بودند. ميانخين سنى آنان حدود احع سال بود. VY درصد شركت كنند كان سابقه كارى ·1 سال و بيشتر داشتند. حدود 90 درصد داراى تحصيلات كارشناسى ارشد و بالاتر بودند. بيشترين درصد ياسخ دهندگان (N درصد) در آموزش عالى و كمترين درصد ( (I/ درصد) در سازمان ملى بهره ورى مشغول به كار بودند. بيشترين نسبت شركت كنند كان (TN/T درصد) اعضاء هيئت علمى دانشخاه، مديرميانى سازمان، كارشناس مسئول، رئيس اداره، دبير آموزشخاه، كارشناس ادارات ورزش و ورمترين نسبت(1/ع درصد) مديران ارشد سازمان هاى ورزشى بودند.

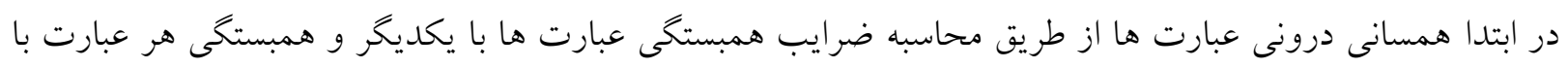

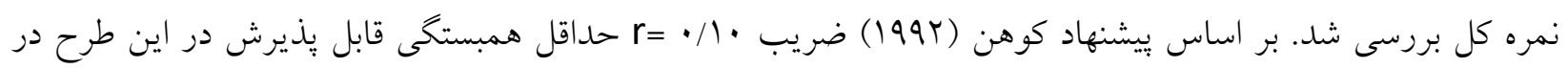

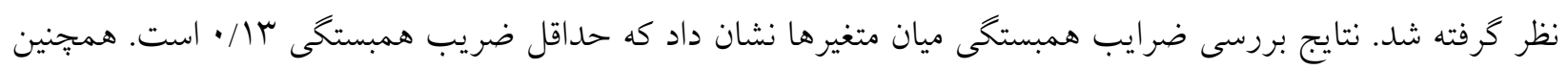

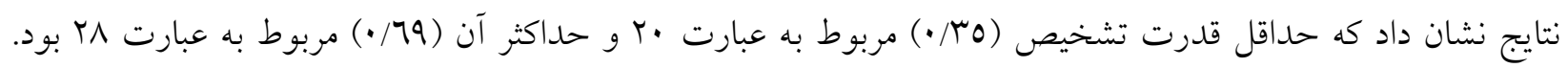

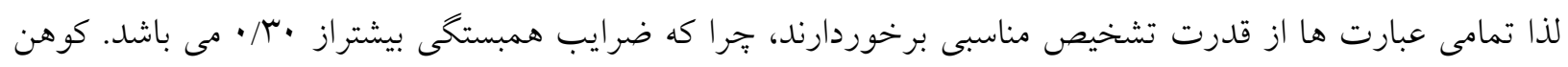
(1994) ضرايب • •r/• و بالاتر را داراى اندازه اثر متوسط به بالا مى داند (19). به منظور بررسى اين كه آيا برسشنامه

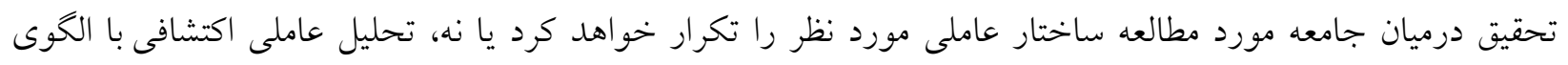

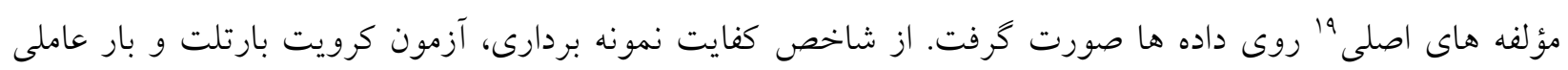
عبارتها در ماتريس عاملى استفاده شد. مقدار ع ع/ •

نشان دهنده قابل توجيه بودن اجراى تحليل عاملى بود (†) (Y). جهت تصميم كيرى در خصوص تعداد عامل هاى استخراجى، به ارزش ويزهْ'، نسبت واريانس تبيين شده توسط هر عامل و نمودار جرخش يافته ارزشهاى ويزه اسكرى "r استناد گرديد. تحليل اوليه ساختارى 10 عاملى با واريانس تبيين

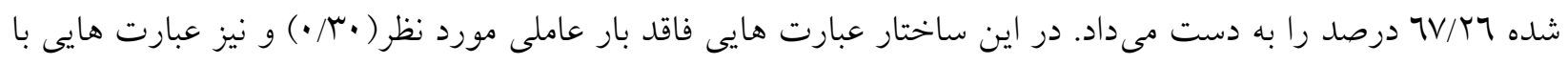
بار عاملى مغشوش ذيل سه يا دو عامل وجود داشت. نمودار اسكرى از اين ساختار حمايت نمى كرد. با حذف عبارت هاى فاقد شرايط فوق، تحليل مجدداً اجرا شد. نتيجه نشان داد كه واريانس تبيين شده در ساختار هفت عاملى برابر با ال7/VV بوده و تمامى عبارتها تنها ذيل يك عامل بار مى شدند. نمودار اسكرى از اين ساختار حمايت كرد و حداقل ارزش ويزه براى عامل ها 7 •/1 بود. نمودار اسكرى در شكل إرائه شده است.

\footnotetext{
19. principal Components (PC)

20. Eigenvalue

21. Scree
}

https://jrsm.khu.ac.ir/ 


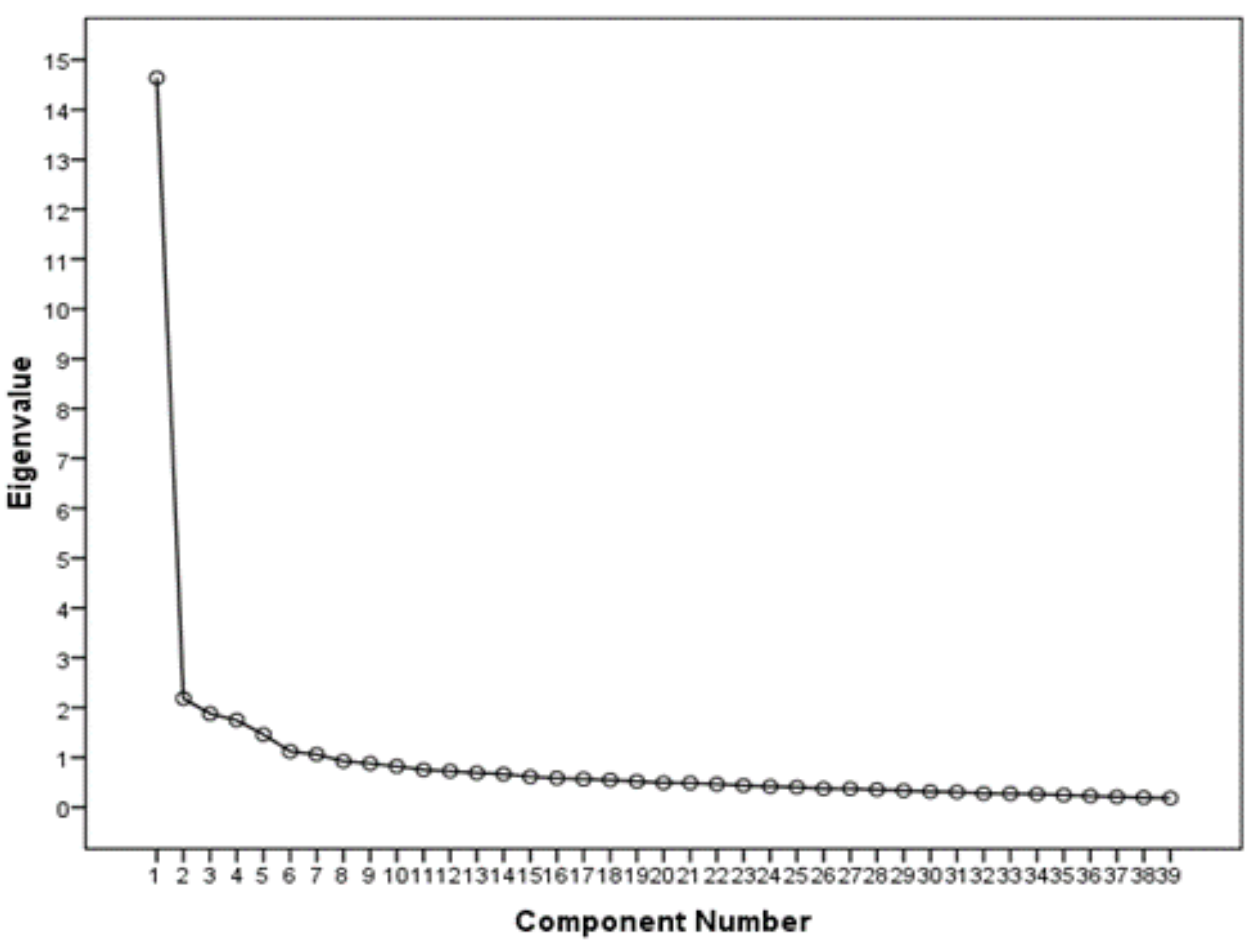

شكل ا. نمودار اسكرى براى عوامل استخراج شده

در ادامه با هدف استخراج عامل هاى منا سب، جرخش يروماكس بَّبه علت همبسته بودن عامل هاى اكتشافى بر اساس

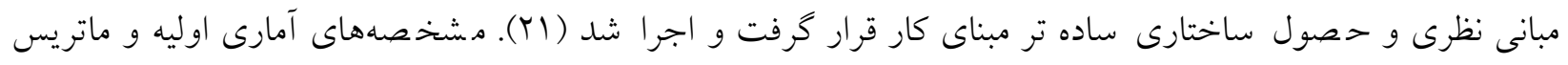
ساختار جرخش يافته در جدول بار ارائه شده است.

22. Promax Rotatino

https://jrsm.khu.ac.ir/ 
جدول r. مشخصههاى آمارى اوليه و ماتريس ساختار هفت عاملى جرخش يافته

\begin{tabular}{|c|c|c|c|c|c|c|c|c|c|c|}
\hline \multicolumn{3}{|c|}{ عامل ها } & \multirow[t]{2}{*}{ شماره عبارت } & \multirow{2}{*}{ رديف } & \multicolumn{4}{|c|}{ عامل ها } & \multirow[t]{2}{*}{ شماره عبارت } & \multirow{2}{*}{ رديف } \\
\hline هفتم & ششم & ينجم & & & جهارم & سوم & دوم & اول & & \\
\hline & & $\cdot / \Lambda \varepsilon$ & $\varepsilon \varepsilon$ & r & & & & $\cdot / 10$ & 0 & 1 \\
\hline & & $\cdot / \mathrm{Vq}$ & 20 & rV & & & & . /Ar & $\varepsilon$ & $r$ \\
\hline & & $\cdot N N^{\mu}$ & $\varepsilon V$ & ץ & & & & $\cdot / \mathrm{Vq}$ & 9 & r \\
\hline & & $\cdot / N 1$ & $\sum 7$ & rq & & & & $\cdot / \mathrm{VI}$ & v & $\varepsilon$ \\
\hline & &.$/ 70$ & $r q$ & $r$. & & & & $\cdot / 7 /$ & $\wedge$ & 0 \\
\hline & & $\cdot \pi V$ & 0. & r & & & &.$/ 7 \mathrm{~V}$ & 1. & 7 \\
\hline & $\cdot / \wedge 1$ & & rv & rY & & & & .107 & $r$ & $\mathrm{v}$ \\
\hline & $\cdot / \wedge 1$ & & $r \varepsilon$ & 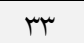 & & & $\cdot \mathrm{NA}$ & & 01 & $\wedge$ \\
\hline & $\cdot N$ & & ro & $r \varepsilon$ & & & $\cdot N V$ & & or & 9 \\
\hline & .100 & & r & ro & & & $\cdot N V$ & & 07 & 1. \\
\hline$\cdot / \mathrm{v}$ & & & ro & m & & & $\cdot N 7$ & & or & 11 \\
\hline.$/ 70$ & & & r & rV & & & $\cdot N 7$ & & or & Ir \\
\hline • & & & rA & rی & & & $\cdot / 71$ & & or & ir \\
\hline .109 & & & rq & ra & & $\cdot / A T$ & & & 10 & $1 \varepsilon$ \\
\hline & & & & & & $\cdot / \mathrm{Na}$ & & & $\pi$ & 10 \\
\hline & & & & & & $\cdot / v 9$ & & & $1 \varepsilon$ & 17 \\
\hline & & & & & & $\cdot / \mathrm{V} A$ & & & $r \varepsilon$ & IV \\
\hline & & & & & & $\cdot / 79$ & & & r & 11 \\
\hline & & & & & $\cdot / \Lambda \varepsilon$ & & & & $7 \pi$ & 19 \\
\hline & & & & & $\cdot / V T$ & & & & TV & $r$. \\
\hline & & & & & $\cdot / \mathrm{NI}$ & & & & 77 & r) \\
\hline & & & & & $\cdot / 7 \varepsilon$ & & & & 71 & rT \\
\hline & & & & & r אר/. & & & & W & r \\
\hline & & & & & $\cdot / 0 \mathrm{~V}$ & & & & $7 \varepsilon$ & $r \varepsilon$ \\
\hline & & & & & $\cdot / \varepsilon r$ & & & & 79 & ro \\
\hline $1 / \cdot 7$ & $1 / 1 r$ & $1 / 27$ & & & 1/No & $1 / M$ & $\Gamma / \Lambda$ & $1 \varepsilon / 7 \varepsilon$ & ارزش ويزه & \\
\hline$T / N T$ & $r / M$ & $r / v \varepsilon$ & & & $\varepsilon / \varepsilon \wedge$ & $\varepsilon / \Lambda r$ & $0 / 7$ & rV/or & واريانس تبيين شده & \\
\hline $71 / \mathrm{VV}$ & $09 / .0$ & $07 / 1 V$ & & & $O r / \Sigma T$ & $\varepsilon V / 9 \varepsilon$ & $\varepsilon \Gamma / \mu$ & rV/or & تبيين شده تجمعى & درصد وار \\
\hline
\end{tabular}

مشخصههاى آمارى اوليه و ماتريس جرخش يافته در جدول نشان داد كه عبارات فاقد بيّيجيدكى بوده و عامل ها شفاف

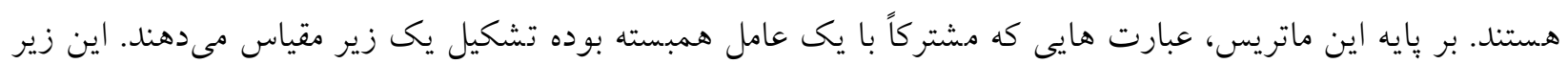
مقياسها به ترتيب بيشترين بار عاملى و نيز مقايسه با ساختار نظرى اوليه نام كذارى كرديد. تعداد عبارات و نام هر يك از آن ها در جدول ب نشان داده شده است. 


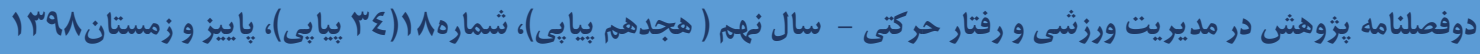

جدولr. تعداد عبارت ها و عوامل تشكيل دهنده يرسشنامه بهره ورى سبز در ورزش ايران

\begin{tabular}{|c|c|c|c|}
\hline عبارات & تعداد عبارات & نام عامل & عامل \\
\hline 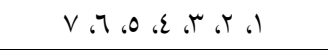 & v & مديريت و برنامه ريزى & اول \\
\hline 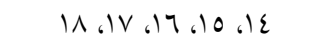 & 0 & 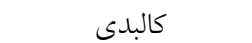 & 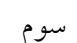 \\
\hline 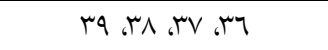 & $\varepsilon$ & فرهنخ و نخرش & هفتم \\
\hline 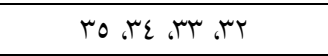 & $\varepsilon$ & نيروى انسانى & ششم \\
\hline 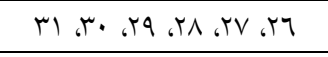 & 7 & آموزش و يُزوهش & يُنجم \\
\hline ג & 7 & كتترل و نظارت & 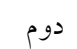 \\
\hline To & v & قوانين و مقررات & جهارم \\
\hline
\end{tabular}

مقايسه ساختار درج شده در جدول ץ با ذسخه اوليه ذشان مى دهد كه از عامل مديريت و برنامه ريزى 0 عبارت، از

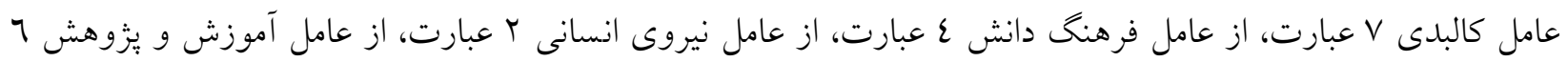
عبارت، از عامل كنترل و نظارت ع عبارت و در نهايت از عامل قوانين و مقررات ب عبارت به علت ندا شتن بار عاملى حداقلى (•r/•) يا بار شدن ذيل دو عامل و بيشتر حذف شدند. يس از اجراى روش تحليل عاملى وتعريف خوشه هاى متمايز، تعيين ضريب بايايى يا همسانى درونى مجموعه عبارت

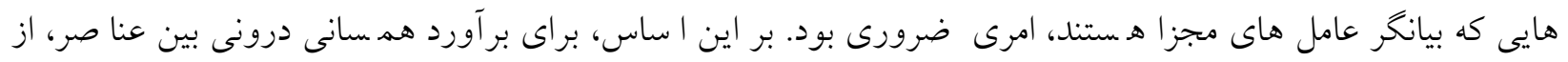
ضرايب آلفاى كرونباخ و دو نيمه كردن كاتمن استفاده شد. نتايج در جدول ع ارائه شده است.

جدول ع. نتايج ضر ايب آلفاى كرونباخ و دو نيمه كردن كاتمن براى تعيين پايائى درونى يرسشنامه بهره ورى سبز در ورزش

\begin{tabular}{|c|c|c|}
\hline ضريب دو نيمه كردن & آلفاى كرونباخ & نام عامل \\
\hline$\cdot / \Lambda \varepsilon$ & $\cdot / A V$ & مديريت و برنامه ريزى \\
\hline$\cdot$. NA & $\cdot / \mathrm{AV}$ & 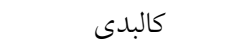 \\
\hline.$/ 27$ & $\cdot / \mathrm{Al}$ & فرهنگ و نخرش \\
\hline$\cdot 110$ & $\cdot / 11$ & نيروى انسانى \\
\hline$\cdot / \mathrm{M}$ & $\cdot / \mathrm{AV}$ & آموزش و يززوهش \\
\hline .110 &.$/ 17$ & كترل و نظارت \\
\hline$\cdot / \Lambda$ & $\cdot / \Lambda r$ & قوانين و مقررات \\
\hline
\end{tabular}

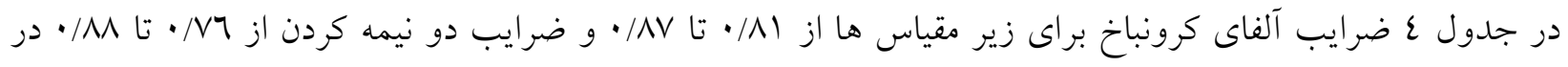

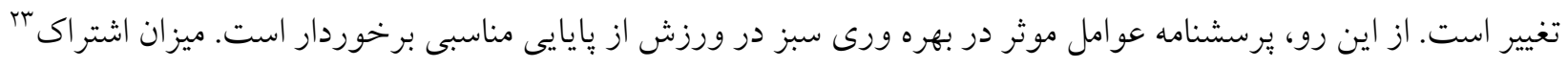
هر يك از عبارت هاى ساختار qه عبارتى، با اجراى تحليل مؤلفههاى اصلى محاسبه شد. كمترين ميزان اشتراك برابر با

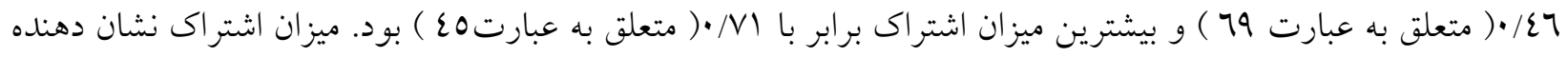

23. Communalities

https://jrsm.khu.ac.ir/ 


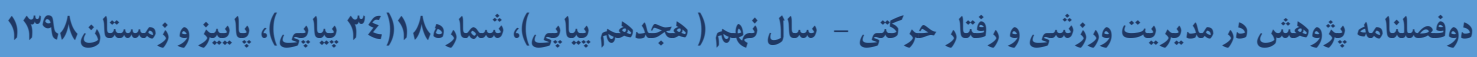

آن است كه هر يك از عبارت ها به جهه مقدار در تشكيل مؤلفه ها سهيم هستند. بر اين اساس به نظر مى رسد تمامى عبارت ها از اشتراك مناسبى برخوردار باشند.

نرمال بودن توزيع متغيرها با آزمون كالموكروف-اسميرنوف يكراههُّبَ بررسى شد. بزركتر بودن سطح معنادارى آزمون

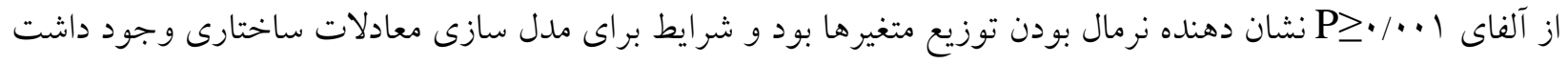

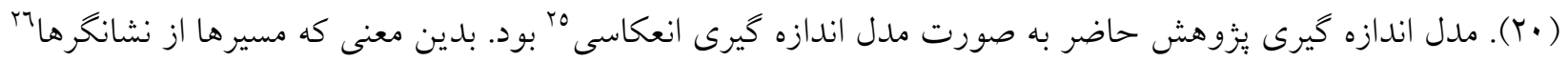

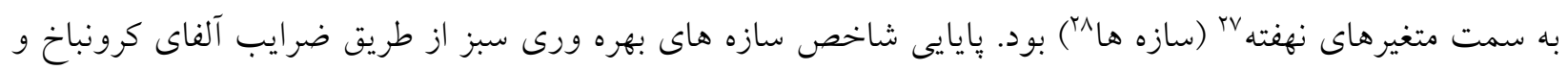

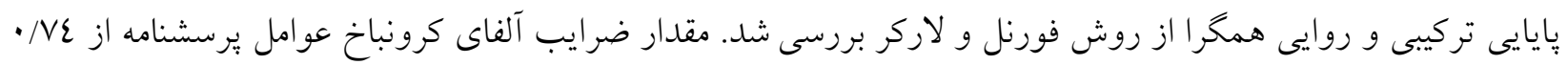

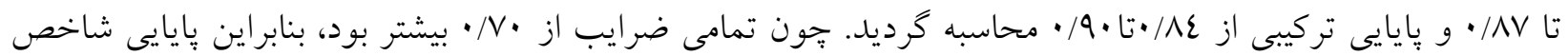

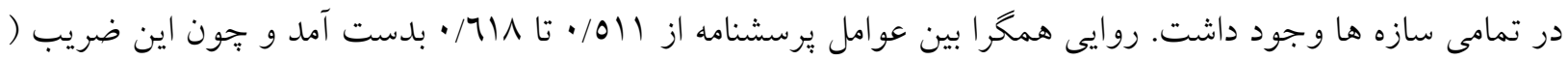
(AVE شاخص ها در جدوله آمده است. جدوله. بررسى بايايى شاخص و روايى همخرا سازه هاى بهره ورى سبز در ورزش

\begin{tabular}{|c|c|c|c|c|}
\hline روايى همخرا & پِايايى تركيبى & آلفاى كرونباخ & بارهاى عاملى & عامل \\
\hline . /or. & $\cdot / 19$ & $\cdot / 10$ & . No & مديريت و برنامه ريزى \\
\hline$\cdot / 7 \cdot r$ & $\cdot / \mathrm{M}$ & $\cdot / \wedge \varepsilon$ & $\cdot / v \varepsilon$ & كالبدى \\
\hline .107. & $\cdot / \wedge \varepsilon$ & $\cdot / V \varepsilon$ & $\cdot / N 7$ & فرهنگ و نخرش \\
\hline$\cdot / 7 \cdot 1$ & $\cdot / 17$ & $\cdot / \mathrm{Va}$ & $\cdot N r$ & نيروى انسانى \\
\hline .1011 & $\cdot 1 / 17$ & $\cdot / \Lambda$ & $\cdot / \Lambda$. & آموزش و يزوهش \\
\hline.$/ 011$ & $\cdot / \mathrm{AV}$ & $\cdot / \wedge 1$ & $\cdot / v \varepsilon$ & كنترل و نظارت \\
\hline.$/ 017$ & $\cdot / \mathrm{MA}$ & $\cdot / \wedge \varepsilon$ & $\cdot N Y$ & قو انين و مقررات \\
\hline .1009 &.$/ 9$ & $\cdot / \wedge \mathrm{V}$ & - & بهره ورى سبز \\
\hline
\end{tabular}

جهت بررسى روايى سازهوr با تحليل عاملى تأييدى از نرم افزارآموس نسخه •r استفاده شد. برآورد مدل با روش بيشينه در ست نمايى .ب صورت گرفت. در ابتدا از تحليل عاملى مرتبه اول استفاده شد. مدل اين تحليل در شكل ب زششان داده

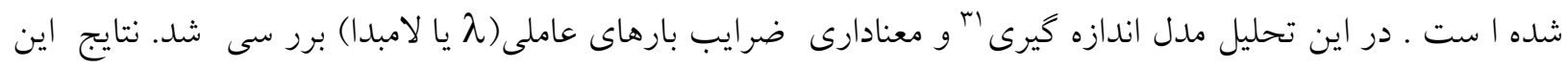

24. One way Kolmogorov-smirnov

25. Reflective measurement model

26. Indicators

27. Latent variables

28. Constructs

29. Construct validity

30. Maximum Likelihood

31. Measurement model

https://jrsm.khu.ac.ir/ 


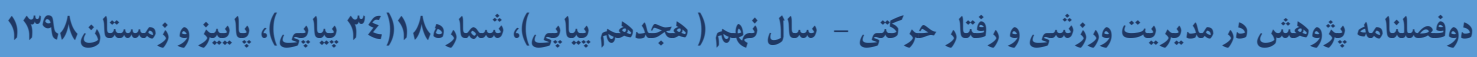

شكل نشان داد كه تمامى بارهاى عاملى بزركتر از • • • هستند. بررسى ضرايب t نيز نشان دادند كه تمامى بارهاى عاملى معنا دارند ( (PS (P).

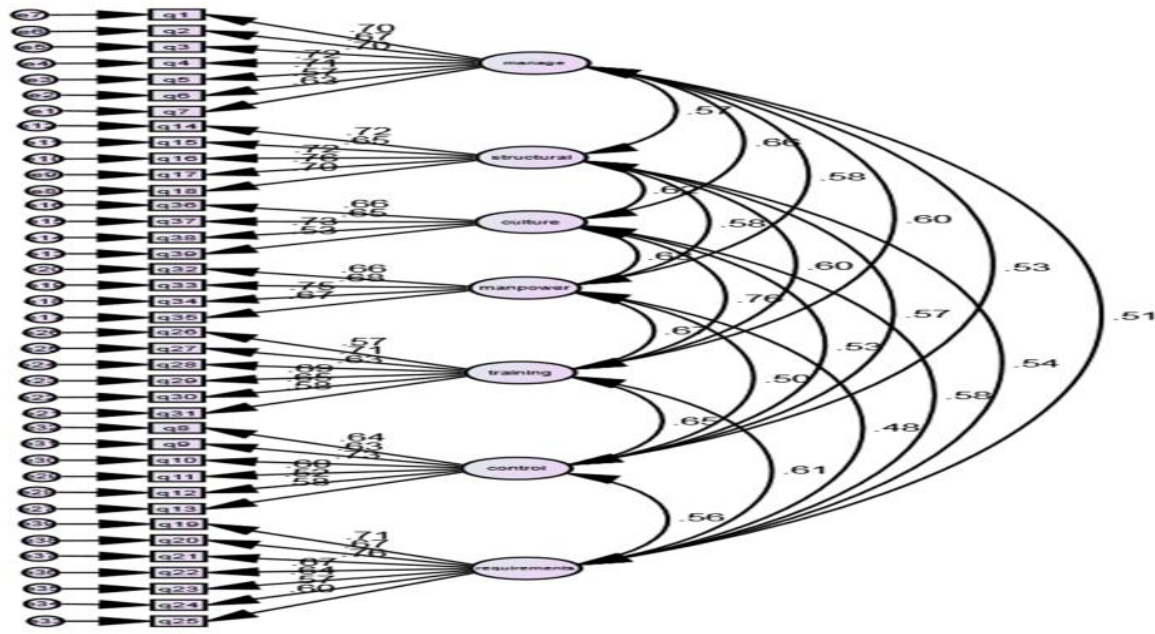

$$
\text { شكل r. مدل تحليل عاملى مرتبه اول }
$$

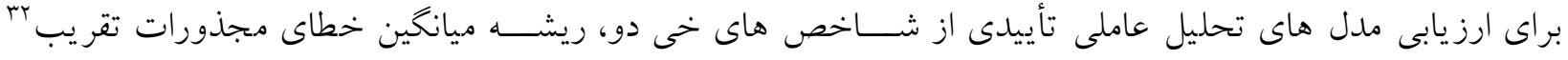

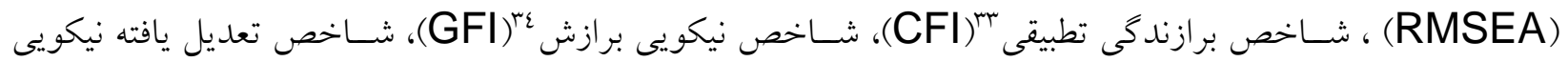
برازش (AGFI) و شاخص برازش افزايشى (IFI) استفاده شد. اين شاخص ها در جدول 7 آمده است.

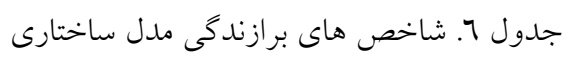

\begin{tabular}{|c|c|c|}
\hline 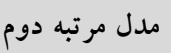 & مدل مرتبه اول & شاخص برازش \\
\hline ITVN/VT & $1 r Y q / 91$ & شاخص خى دو (X) \\
\hline 790 & 711 & درجات آزادى(df) \\
\hline.$/ \cdot 1$ &.$/ \cdot 1$ & سطح معنادارى(P) \\
\hline 1/91 & $1 / 90$ & نسبت خى دو به درجات آزادى(X²/df) \\
\hline .1 .0 & .1 .0 & ريشه ميانكين خطاى مجذورات تقريب(RMSEA) \\
\hline$\cdot / 9 \cdot$ &.$/ 91$ & شاخص نيكويى برازش (GFI) \\
\hline$\cdot / 19$ & $\cdot 1 / 9$ & شاخص تعديل يافته نيكويى برازش(AGFI) \\
\hline$\cdot / 94$ &.$/ 94$ & شاخص برازندكى تطبيقى(CFI) \\
\hline . $19 \pi$ & . $/ 9 \mathrm{r}$ & شاخص برازش افزايشى (IFI) \\
\hline
\end{tabular}

32. Root Mean Square Error of Approximation (RMSEA)

33. Comparative Fit Index (CFI)

34. Goodness of Fit Index (GFI)

35. Adjusted Goodness of Fit Index (AGFI)

36. Incremental Fit Index (NFI) 


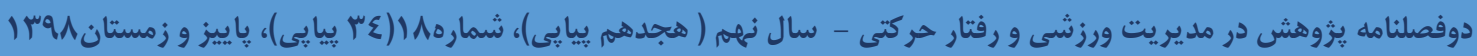

نتايج بررسى شاخص هاى جدول 7 نشان مى دهد كه مدل مرتبه اول از برازش مناسبى برخوردار است. و در دامنه مدل هاى خوب قرار گرفته است. سبس جهت دستيابى به ساختار عاملى دقيق تر از تحليل عاملى مرتبه دوم استفاده شد. مدل تحليل عاملى مرتبه دوم در شكل ب آورده شده است.

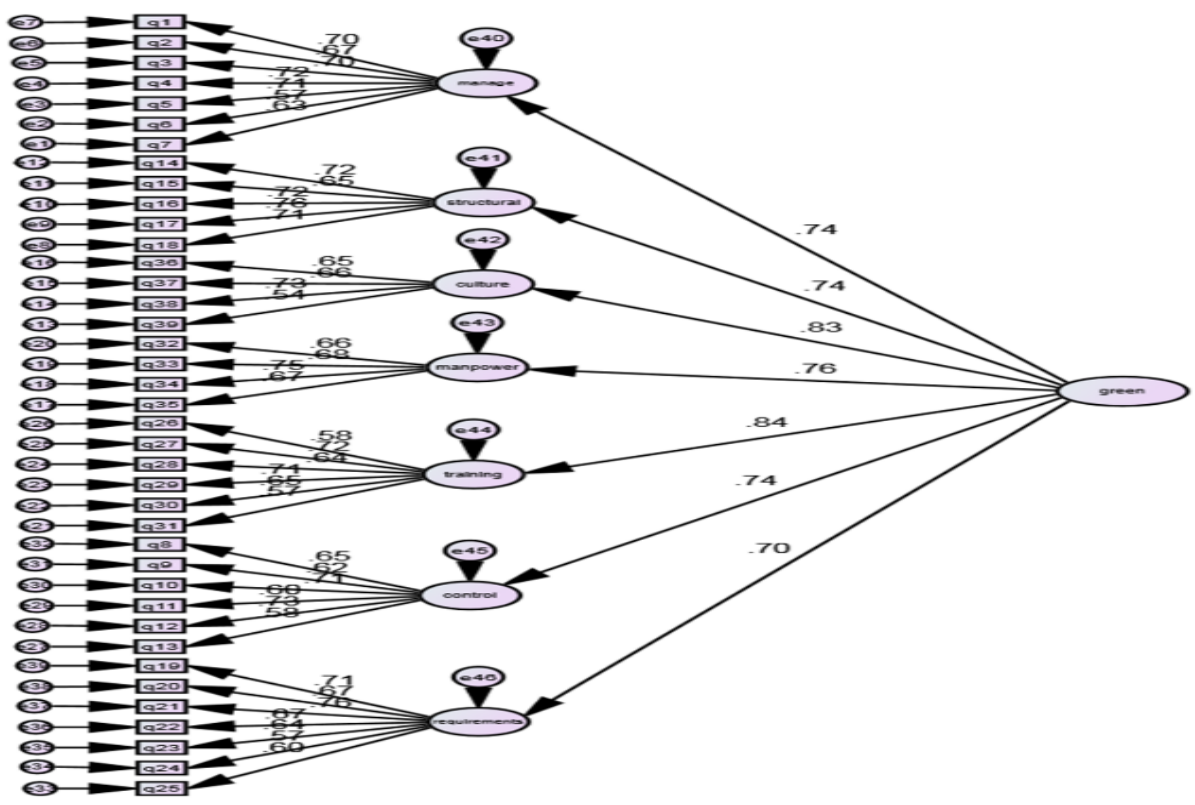

شكل r. مدل تحليل عاملى مرتبه دوم

بررسى ضرايب شكل س نشان مى دهد كه تمامى بارهاى عاملى بزركتر از •0/ • هستند. بررسى ضرايب t نيز نشان دادند

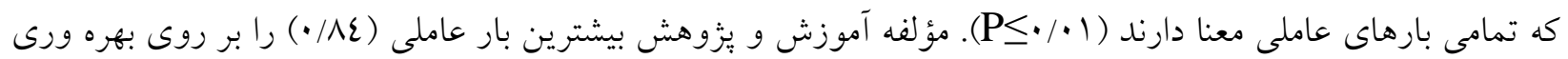
سبز در ورزش دارد. شاخص هاى برازندكى مرتبه دوم در جدول 77 آمده است. بخش ديخر از سنجش يايايى ابزار مربوط به يايايى هر معرف انعكاسى و سازه متناظر با آن است كه با بار عاملى نشان داده مى شود. ضرايب مناسب براى اين شاخص مقادير ع/• و بالاتر را شامل مى شود. بارهاى عاملى نشانخرها بر روى سازه هفتخانه بهره ورى سبز در جدول V آورده شده است. نتايج اين جدول نشان مى دهد كه بارهاى عاملى در تمامى

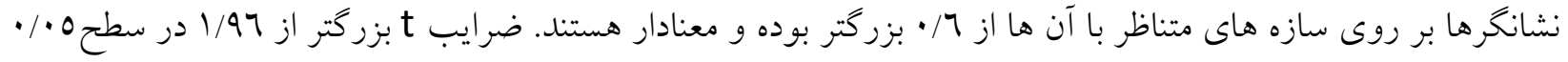
معنادارند (YT). 


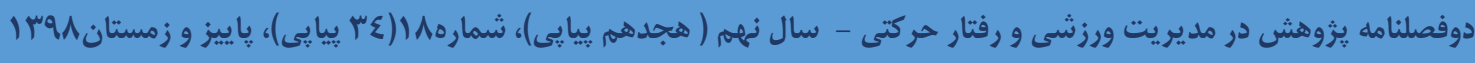

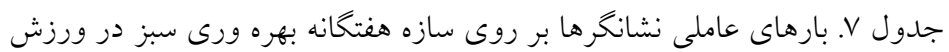

\begin{tabular}{|c|c|c|}
\hline t & نشانخر ها & سازه \\
\hline re/OV & ا.طراحى سبك مديريتى مبتنى بر نظام (زيست كارآمد)) در ورزش كشور & \multirow{7}{*}{$\begin{array}{c}3 \\
3 \\
3 \\
3 \\
3 \\
3 \\
3 \\
3 \\
3 \\
3\end{array}$} \\
\hline $19 / 00$ & r.تعامل با سازمان ها در مبحث (بهرهورى سبز) جهت استفاده از ظرفيت و مساعدت آن ها در ورزش & \\
\hline$r q / V r$ & "ابرخوردارى مديران ورزشى كشور از دانش و بينش "زيست محيطى) و به كارگيرى آن در اجراى بهره ورى سبز & \\
\hline$r 7 / r q$ & عُبرنامه ريزى جهت مشاركت كاركنان و مشتريان در اجراى استراتزى بهره ورى سبز (جهت ترغيب كاركنان) & \\
\hline TV/VI & 0.همكارى و تعامل با حاميان مالى و تأمين كنندكان مصالح و مواد اوليه و... مورد نياز سازمان هاى ورزشى & \\
\hline $11 / 97$ & 7.عملكرد مديران ورزشى در قبال ايمنى، بهداشت و رفاه كاركنان و كسب مشاركت فكرى از آنان & \\
\hline IT/VT & V. يُش بينى و اختصاص بودجه براى طراحى، ساخت و مديريت فضاهاى ورزشى طبق استاندارد محيط زيستى & \\
\hline Tr/OT & ع ا. توجه به ضرورت احداث (فضاى ورزشى جديد)) با نظر به هزينه هاى (اقتصادى، اجتماعى و...) درازمدت آن & \multirow{5}{*}{ y. } \\
\hline$r \mu / Y \varepsilon$ & 10. توجه به استاندارد ها و معيارهاى طر احى فضاهاى ورزشى طبق فدراسيون ورزشى رشته مورد نظر & \\
\hline$r \wedge / q$. & 17. توجه به شرايط فرهنكى و اجتماعى منطقه در طراحى و احداث فضاهاى ورزشى & \\
\hline ro/10 & VV ا. توسعه يذيرى فضاهاى ورزشى طراحى شده و تناسب آن با جمعيت استفاده كندگان در آينده & \\
\hline rO/Tr & 11. انطباق يذيرى و انعطاف يذيرى اماكن ورزشى كشور با نيازهاى (آموزشى، سنى، جنسيتى و...) مختلف كاربران & \\
\hline ro/79 & حس. ترويج فرهنگ سبز انديشيدن درفضاى كارى سازمان هاى ورزشى & \multirow{4}{*}{$\begin{array}{l}.3 \\
13 \\
13 \\
103 \\
13\end{array}$} \\
\hline TM/VV & VVV تغيير نخرش و باور مديران ورزش بر اين كه تحقق توسعه پِايدار در ورزش، مستلزم اجراى استراتزى بهره & \\
\hline ro/rT & 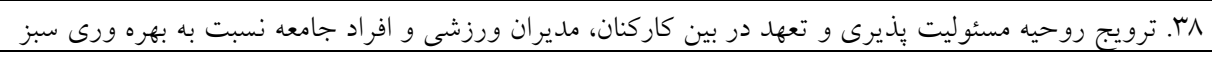 & \\
\hline $10 / 11$ & qجr. ترويج فرهنگ صرفه جويى منابع و كاهش هزينه سازمان هاى ورزشى و احساس مسئوليت در خصوص & \\
\hline$\mu \cdot / \cdot 0$ & rr. ميزان تحصيلات تخصصى كاركنان، مديران و سريرستان ورزش كشور & \multirow{4}{*}{$\begin{array}{l}3: \\
y \\
\frac{3}{3} \\
3 \\
3\end{array}$} \\
\hline$r T / T \Lambda$ & ساس. ميزان تجربه كاركنان، مديران و سريرستان شاغل در بخش هاى مختلف ورزش & \\
\hline$r v / l$. & عَr. تخصيص حقوق كافى و تسهيلات رفاهى براى كاركنان، مديران و مجريان استراتزى بهره ورى سبز در ورزش & \\
\hline$r 9 / 19$ & هrr. به كاركيرى مربيان و مديران ورزشى شايسته و كارآمد جهت ارائه كالا و خدمات مناسب جهت جذب مشترى & \\
\hline $10 / 19$ & 7r. آكاه سازى و آموزش اهداف و استراتزى بهره ورى سبز به كاركنان و استفاده كنندكان از كالاو خدمات & \multirow{6}{*}{$\begin{array}{c}1 \overline{3} \\
3 \\
-3 \\
9 \\
3 \\
3 \\
3 \\
3 \\
3\end{array}$} \\
\hline rT/0T & VV. تربيت نيروى انسانى دانشخاهى با كرايش تحصيلى (بهره ورى سبز) جهت اشتغال و مديريت دراماكن ورزشى & \\
\hline $11 / 77$ & T^. بررسى اثرات مثبت توسعه و اجراى بهره ورى سبز بركيفيت زندگى، بهداشت و...استفاده كنندگان كالا و & \\
\hline$r \cdot / \varepsilon\rceil$ & 19. بررسى تحليلى انواع فناورى هاى جديد مورد استفاده جهت صرفه جويى منابع و...در بخش هاى عملياتى & \\
\hline $19 / 90$ & •r.r. بررسى راهكارهاى تدوين برنامه هاى جامع و هماهنگ به منظور تعيين خط و مشى هاى زيست محيطى & \\
\hline $17 / 11$ & اسا. بررسى، تشريح و تبيين ويزگى هاى مطلوب كالا و خدمات ورزشى مناسب براى عرضه به استفاده كنندگان & \\
\hline 19/VV & ^.. تعيين و استخراج شاخص هاى اندازه گيرى، ارزيابى دوره اى منظم و جِى ليست هاى نظارتى بهره ورى سبز & \multirow{6}{*}{ 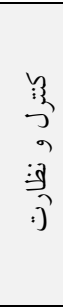 } \\
\hline 19/0r & 9. ارزيابى و نظارت كافى در فرايندطراحى، ساخت، بهره بردارى و مديريت اماكن و فضاهاى ورزشى كشور & \\
\hline$r \cdot / Y_{1}$ & •l. كترل و نظارت برتهيه وسايل و تجهيزات مورد نياز منطبق با شاخص ها ى زيست محيطى و فدراسيون & \\
\hline$|\wedge / \wedge|$ & 11. كنترل و بازبينى كيفيت روشنايى، سيستم هاى سرمايشى، كرمايشى و تهويه هوا (به ويزه در اماكن سريوشيده) & \\
\hline rN/Or & rا ا. معاينه، وارسى ،تعمير و ترميم روزانه وسايل و تجهيزات ورزشى پِ از انجام تمرين و مسابقات & \\
\hline $1 \Lambda / \cdot \varepsilon$ & با. نظارت و كنترل اعتبارات تخصيص يافته و نحوه هزينه كرد آن در طى فرايند طراحى، ساخت و مديريت اماكن & \\
\hline$r \varepsilon / 7$. & 19. تنظيم و ارائه اصول و نظامى هدايتخر جهت دستيابى به اهداف، سياست و اجراى استراتزى بهرهورى & \multirow{7}{*}{$\begin{array}{l}\frac{2}{3} \\
.3 \\
5 \\
: 3 \\
\frac{3}{3}\end{array}$} \\
\hline$r 7 / 10$ & • r اتخاذ ضو ابط و تمهيدات لازم جهت گرايش بيشتر مالكان، مديران و مجريان به استراتزى بهره ورى سبز & \\
\hline$r \cdot / \Lambda \cdot$ & آ. تنظيم آيين نامه امتياز دهى (زيست محيطى، بهداشتى...) فضاهاى ورزشى و ارائه تسهيلات بهتر به مجريان آن & \\
\hline $19 / 21$ & r Y. تعيين ضوابط و معيارهاى لازم به منظور كاهش مصرف منابع و انرزى و مديريت بهينه آن در اماكن ورزشى & \\
\hline$r \cdot / T_{0}$ & سז. تعيين ضو ابط و معيارهاى ايمنى، بهداشتى و ... در طراحى، ساخت و بهره بردارى فضا ها و تجهيزات ورزشى & \\
\hline $\mathrm{IV} / \mathrm{r} \cdot$ & ع ז.تنظيم دستور العمل در خصوص كيفيت كالا و خدمات ارائه شده توسط سازمان هاى ورزشى(اركونومى بدن،... & \\
\hline$r \cdot / v \varepsilon$ & م. اعمال مقررات منع ايجاد آلايندههاى هوا، آب و مزاحمت هاى نور & \\
\hline
\end{tabular}

\section{https://jrsm.khu.ac.ir/}




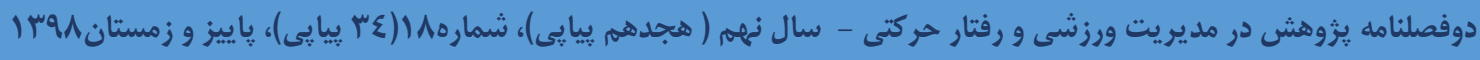

\section{بحث و نتيجه تيرى}

شواهد و تجربيات مؤيد اين واقعيت است كه ورزش مى تواند به عنوان ابزارى بسيار مؤثر و كارآمد و در عين حال ابزارى كم هزينه در جهت تحقق اهداف مربوط به توسعه پيايدار بكار گرفته شود (T/). بهره ورى سبز كليد اصلى رشد و

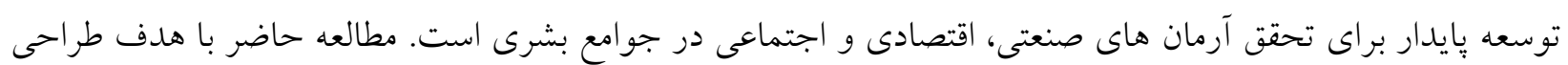
ابزار سنجش عوامل مؤثر در بياده سازى استراتزى بهره ورى سبز در ورزش انجام شد. مؤلفه هاى اصلى مؤثر در بياده سازى استراتزى بهره ورى سبز در ورزش با توجه به ادبيات موضوع و نظر خواهى از متخصصين و بِ إز انجام تحليل

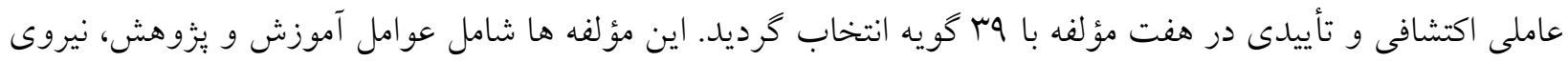
انسانى، فرهنگ و نخرش، قوانين و مقررات، كنترل و نظارت، مديريت و برنامه ريزى و كالبدى مى باشد. نتايج نشان داد

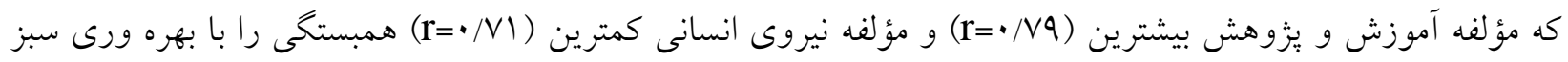

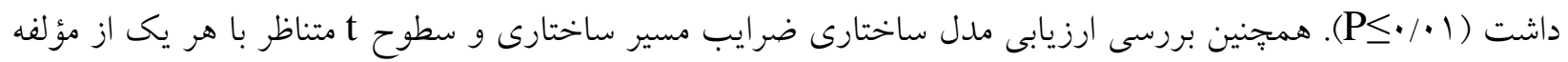
ها، نشان داد كه ضرايب مسير سازه ها به استراتزى بهره ورى سبز معنادار هستند. براى اولويت بندى مؤلفه ها از تحليل ماتريس اهميت - عملكرد استفاده شد. اولين عامل، آموزش و يزوهش بود كه با ارزش ويزٔه (1/27)، مقدار(Y/VI درصد) واريانس بهره ورى سبز را تبيين مى كرد. شش كويه منعكس كننده اين عامل بود. تربيت نيروى انسانى دانشخاهى با گرايش رشته تحصيلى بهره ورى سبز، بررسى تحليلى انواع فناورى جديد در صرفه جويى منابع و انرزى، بررسى اثرات مثبت توسعه و بياده سازى بهره ورى

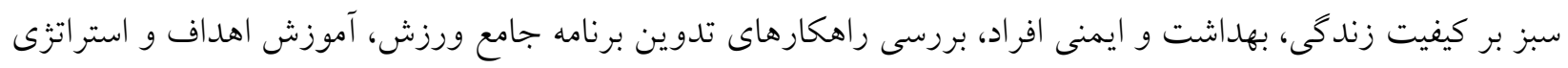
بهره ورى سبز، تشريح و تبيين ويزگى هاى كالا و خدمات مطلوب ورزشى به ترتيب از مهم ترين زير مؤلفهُ آن بود. حاج

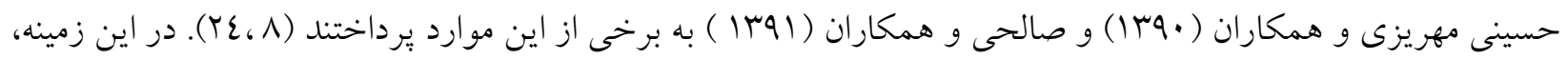
براتيسادا (10 (T) به ضرورت افزايش آكاهى و توسعه مهارت ها جهت ارتقاء توسعه سبز ( با تمركز بر بهره ورى سبز) اشاره داشته است (Y0). فلاح و همكاران (ع (1)) آموزش و يزوهش را به عنوان سومين مؤلفهُ اصلى بهره ورى سبز ذكر نمودند (1). بنابراين با آموزش كاركنان و بركزارى دوره هاى آموزشى مورد نياز و نيز انجام يزوهش هاى كاربردى و بنيادى مرتبط، مى توان تمهيدات لازم را براى بياده سازى و سنجش استراتزى بهره ورى سبز فرآهم آورد. دومين عامل،

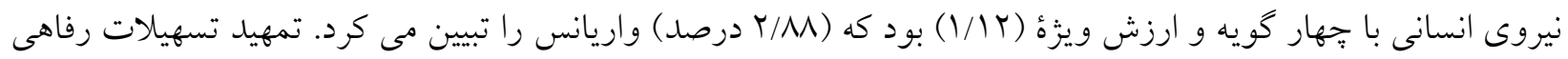

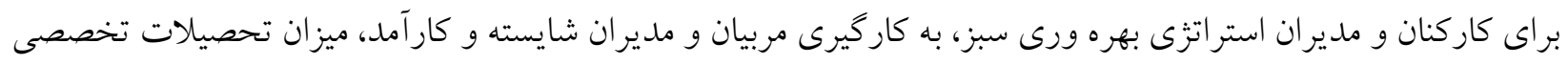
و تجربه مديران در حوزه بهره ورى سبز، از زير مؤلفهُ نيروى انسانى ذكر شدند. يافته هاى اين بخش در راستاى تحقيقات

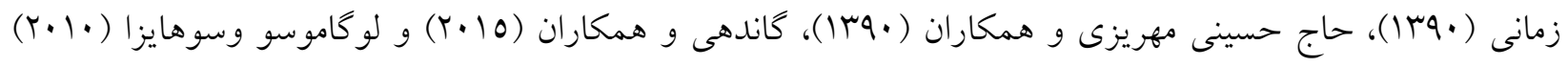
مى باشد (7، V،9، • (1). از اين رو تخصص مرتبط مديران و توجه آنان به داشتن افرادى با سابقه، با انخيزه، مثبتنخر، ايجاد 


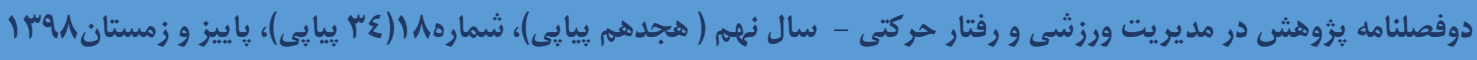

جوى صميمانه در محيط كار بين كاركنان و مديران، سبب بوجود آمدن حس رقابت و افزايش بهره ورى سازمان مى شود

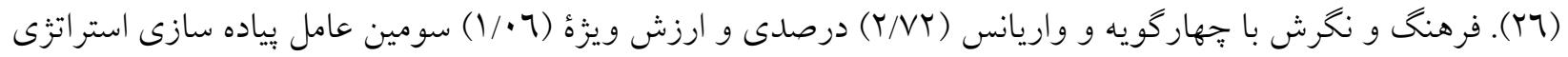
بهره ورى سبز بود. ترويج روحيه تعهد و مسئوليت يذيرى، تغيير نخرش افراد نسبت به بهره ورى سبز و نقش آن در توسعه يايدار، ترويج فرهنگ سبز انديشيدن در فضاى كارى، ترويج فرهنگ صرفه جويى و كاهش هزينه در ورزش و احساس مسئوليت در خصوص نسل هاى آينده، از مهم ترين گويه هاى مؤلفه فرهنگ و نحُش بود. اين نتايج با يافته

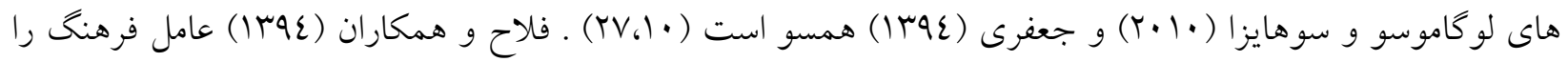
به عنوان دومين مؤلفهُ اصلى بهره ورى سبز ذكر نمودند (1). جعفرى و معمار زاده طهران (147 (1) اهميت عامل فرهنگ

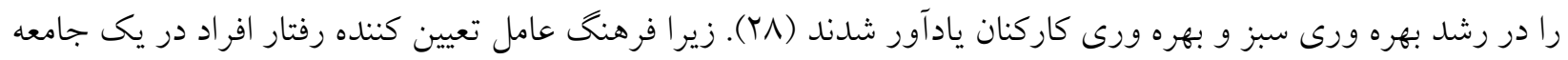
است و رفتارهاى زيست محيطى تك تكى افراد نشات گرفته از آن مى باشد (Y9). جهارمين عامل با ميزان (^ع/ع) درصد تبيين واريانس و ارزش ويزٔه (1/V0 ) مربوط به عامل قوانين و مقررات بود. هفت كوئُ در اين عامل قرار كرفتند. تنظيم آيين نامه امتياز دهى زيست محيطى در فضاهاى ورزشى، تنظيم و ارائه اصول و نظام هدايتخر در استراتزى بهره ورى سبز و الزام همه كاركزاران در اقدام به آن، اتخاذ سياست هاى حمايتى و تشويقى جهت مجريان بهره ورى سبز، تعيين ضوابط و معيارهاى لازم جهت كاهش مصرف منابع و انرزى، تعيين ضو ابط و معيارهاى بهداشتى و ايمنى در روند احداث و مديريت اماكن ورزشى، اعمال مقررات منع ايجاد آلاينده هاى هوا، آب و مزاحمت هاى نور و صوت و تبيين و تنظيم دستور العمل كيفيت كالا و خدمات در سازمان هاى ورزشى، از مهم ترين زير مؤلفه هاى قوانين و مقررات بود. هويى شى و همكاران (Y. V (Y) اتخاذ مقررات استراتزيكى را به طور مثبت با بهره ورى سبز مرتبط دانستند (1). اين مؤلفه توسط فلاح و همكاران (ع وسا) به عنوان اصلى ترين مؤلفه بهره ورى سبز در سازمان مترو معرفى شده است (1). يافته هاى تحقيق، بيانكر كستردكى و عمق اين مؤلفه است و بايد اذعان نمود كه رعايت قوانين و مقررات و تلاش براى درست انجام دادن كارها باعث تداوم، رشد و شكوفايى سازمان هاى ورزشى مىشود.

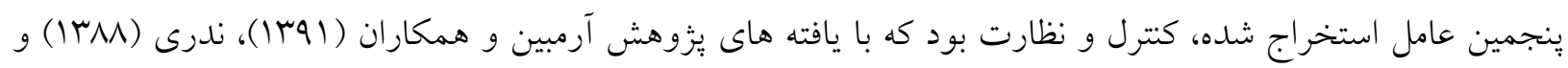
غلامرضا يور (9/1) همسو مى باشد. آن ها نيز بخش نظارت و ارزيابى را به عنوان عامل مؤثر در بهره ورى اماكن

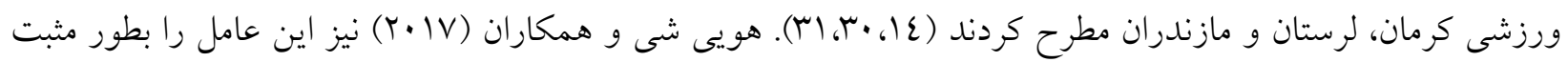
با بهره ورى سبز مرتبط دانستند (1). شش گويةٔ در اين عامل قرارگرفته است و (•0/7) درصد از واريانس بهره ورى سبز را با ارزش ويزهة (Y/IN) تبيين مى كند. وارسى و تعمير منظم وسايل و تجهيزات ورزشى، نظارت بر تهيه وسايل وتجهيزات ورزشى مورد نياز منطبق با معيارهاى فدراسيون مربوطه، استخراج شاخص هاى ارزيابى، انجام ارزيابى دوره اى منظم، ارزيابى و نظارت كافى در فرايند طراحى، ساخت، بهره بردارى و مديريت فضاهاى ورزشى، كنترل كيفيت روشنايى، سيستم هاى سرمايشى، گرمايشى و تهويه هوا و نظارت و كنترل بر اعتبارات و نحوه هزينه كرد آن از مهم ترين كويه هاى كتترل و نظارت است. به نظر مى رسد كنترل و نظارت به عنوان ابزارى مطمئن، با ايجاد نظم در تمامى فرآيند 


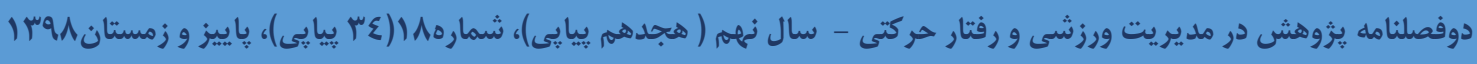

سازمان هاى ورزشى، موجب تحقق برنامه هاى استراتزى بهره ورى سبز مى شود. ششمين عامل با (rV/Or) درصد

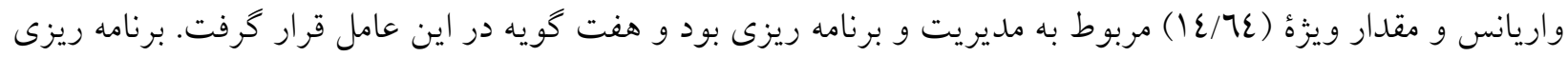
جهت مشاركت سازمان يافته و مؤثركاركنان، همكارى و تعامل با سرمايه كذاران و تامين كنند كان مواد اوليه، طراحى سبك مديريتى مبتنى بر نظام زيست كارآمد (نظامى كه از نظر اقتصادى كارآمد و از نظر زيست محيطى بى خطر باشد)، برخوردارى مديران ورزشى از دانش و بينش زيست محيطى، تعامل با ساير سازمان هاى مرتبط با بهره ورى سبز، اقدامات مديران ورزشى در قبال رفاه كاركنان و كسب مشاركت فكرى از آنان و بيش بينى و تخصيص بودجيه كافى براى ساخت، نحهارى و مديريت فضاهاى ورزشى از مهم ترين زير مؤلفهُ بخش مديريت و برنامه ريزى مى باشد. يافته هاى اين بخش

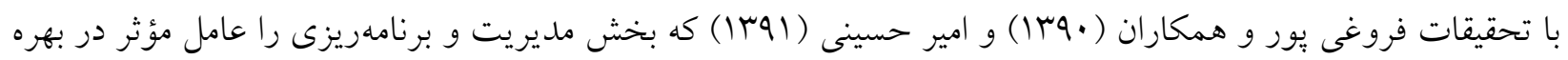

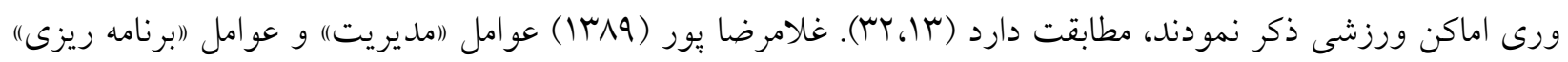
را به طور مجزا به عنوان دو مولفهُ اصلى مؤثر در بهره ورى اماكن ورزشى مازندران اعلام كرد ( آس). كاندهى و همكاران (10 (Y) تعهد بالاى مديريتى را از عوامل مؤثر در موفقيت طرح هاى زنجيره تامين سبز مطرح نمودند (9). در تحقيق فلاح

و همكار ان (عابrا) مؤلفه مديريت جزو مؤلفه هاى اصلى و از لحاظ رتبه بندى در جايگاه جهارم قرار گرفته است (1).

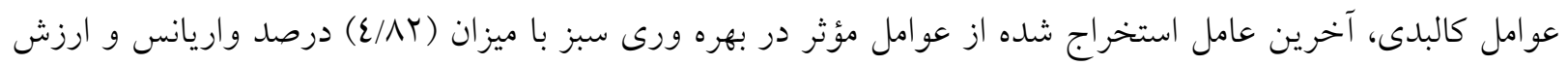
ويزٔه (1/11) بود. اين مفهوم بدين معنا است كه قابليت توسعه يذيرى فضاها، ملاحظه شرايط فرهنكى و اجتماعى، توجه به ضرورت احداث فضاى ورزشى جديد، انطباقيذيرى و انعطاف يذيرى فضا هاى ورزشى و نيز توجه به استانداردها و ضوابط طراحى فضاهاى ورزشى رشته مورد نظر از مهم ترين شاخص هاى عوامل كالبدى مى باشد. نتايج اين بخش در راستاى يزوهش زيانح و همكاران (Y.IV) بوده كه رشد بهره ورى سبز در سطح كلان را مستلزم بيشرفت تكنولوزى، تغيير كارايى فنى و ساختارى بيان نمودند (سش). عليرغم اين كه اين مؤلفه از حيث اهميت در آخرين اولويت قرئ قرار كرفته اما به دليل كسترهى تأثيرش در طراحى، ساخت، تعميرات و نخهدارى فضاهاى ورزشى از عوامل حائز اهميت بوده است است

$$
\text { و از اركان مهم ورزش كشور محسوب مي شود. }
$$

با وجود محدوديت هاى يزوهش از جمله، آكاهى محدود برخى از مديران و مصاحبه شوندكان درخصوص مفرونهوم بهره ورى سبز و عدم كنترل دقيق بر ميزان دقت نمونه ها در باسخكويى به سؤالات يرسش نامه، ليكن ابزار طراحى شده با توجه به روايى و ويايايى مناسب آن براى سنجش عوامل مؤثر در بهره ورى سبز در ورزش قابل استفاده مى باشد. از اين

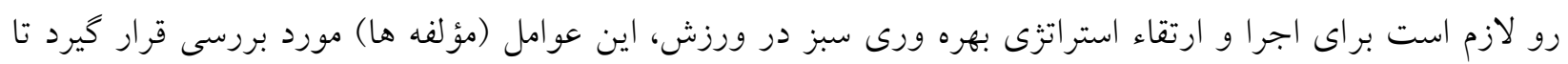
زمينه تجلى آن در سازمان هاى ورزشى فراهم شود. اين ابزار مى تواند از طريق بازاريابى سبز (ارائه كالا و خدماتى كه

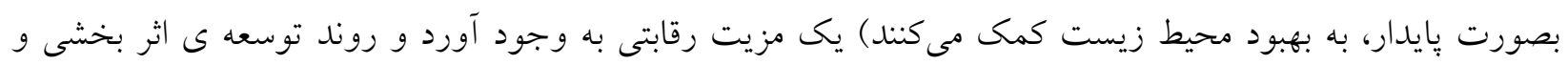
كارائى سازمان هاى ورزشى را بهبود بخشد، بنابراين بيشنهاد مى شود براى سنجش بهره ورى سبز در ورزش مورد استفاده قرار كيرد. به محققين آينده هم بيشنهاد مى شود ضمن انجام تحقيقات مشابه در سازمان هاى ورزشى دولتى و خصوصى بـى 


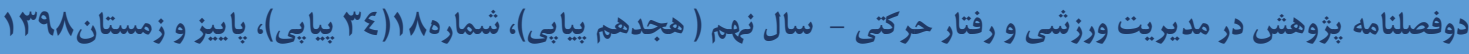

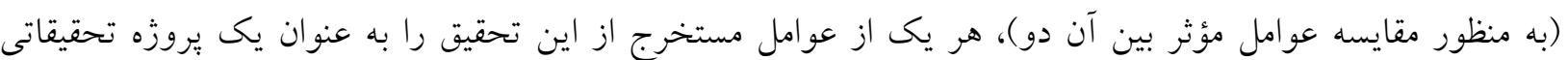
جداگانه (در يكى سازمان ورزشى و يا فدراسيون ورزشى) مورد بررسى قرار دهند.

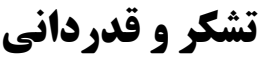

از همكارى صميمانه اساتيد دانشخاه، كارشناسان محيط زيست و تمامى مديران ورزشى كه ما را در انجام اين بزوهش يارى نمودند، تشكر و قدردانى مى گردد. منابع

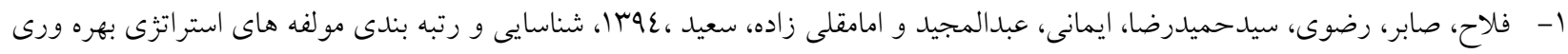

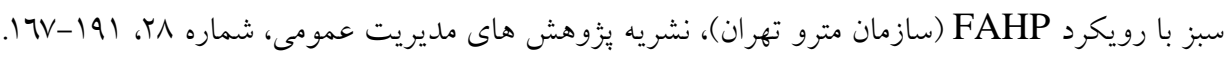

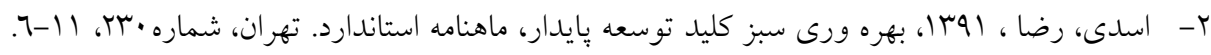

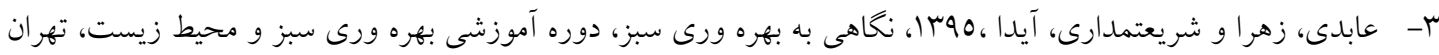

4- Masood, A. K.m, Abbasi, S. A, 2015, Workshop on Policy Development for Green Productivity Promotion, Taipei, Republic of China, 17-22.

5- Kamrul .A, Shams. R, (2017), Green public procurement implementation challenges in Australian public healthcare secto. Journal of Cleaner Production, 152, 181-197.

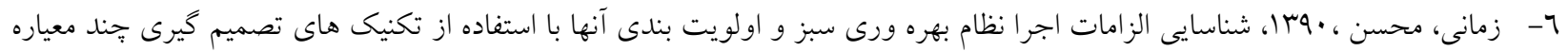
MCDM

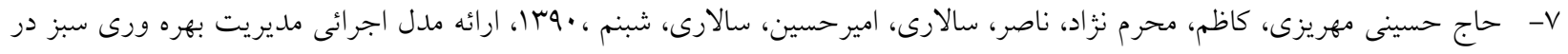
صنايع نساجى، سومين كنفرانس ملى مهندسى نساجى و يوشاك، دانشگاه آزاد اسلامى واحد يزد، 1-1 .

^- طوبى، زينب، لاهيجانيان، اكرم الملوى، يوسفى، حسين ، بوس ا، شناسايى و اولويت بندى مؤلفه هاى بهره ورى سبز در كارخانه زمزم تهر ان

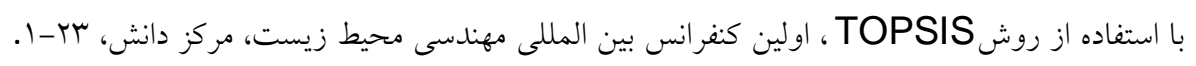

9- Gandhi, M. Selladurai, V. Santhi.P, 2006, Green productivity indexing : A practical step towards integrating environmental protection into corporate performance, International Journal of Productivity and Performance Management, Vol, 55, No (7).

10- Logamuthu and Suhaiza, Z, 2010, Factors Influencing the Implementation of Green Productivity Practices and its Effect on the Organisational Performance: A Comparision Study Between EMS 14001 and ISO 9000 Certified Companies in Malaysia, Asian Journal of Information Technology, 45-53.

11- Hui, X. Yi-jun, Yuan. Jing-jing, H, 2017, Different Types of Environmental Regulations and Heterogeneous Influence on Green Productivity: Evidence from China, Ecological Economics, Vol 132, 104-112.

12- Batuwitage, L. P, 2015, Policy Development for Green Productivity Promotion in the Srilanka, Workshop on Policy Development for Green Productivity Promotion, Taipei, Republic of China, 54-55.

سا - فروغى يور، حميد، صابونجى، رضا، تيّ، هادى، •وجا، ارزيابى بهره ورى اماكن ورزشى از ديدكاه دبيران تربيت بدنى همدان، نشريه

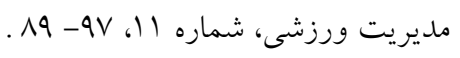

https://jrsm.khu.ac.ir/ 


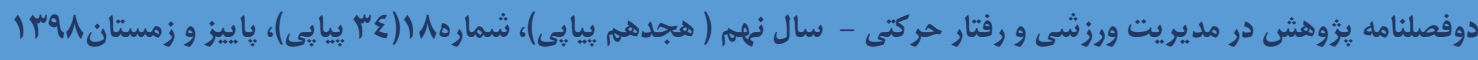

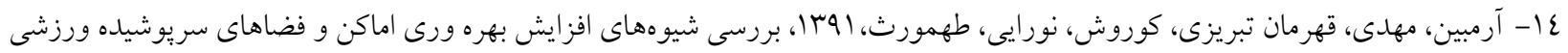
از ديدكاه مديران ورزشى استان كرمان، بايان نامه كارشناسى ارشد تربيت بدنى، دانشخاه شهيد باهنر كرمان .

10- مسجدى، محمد، رضايى صوفى، مرتضى،90با، عوامل موثر بر افزايش بهره ورى اماكن و فضاهاى ورزشى شهردارى در استان اصفهان،

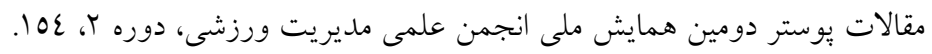

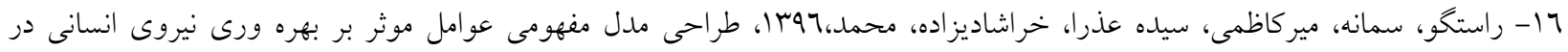

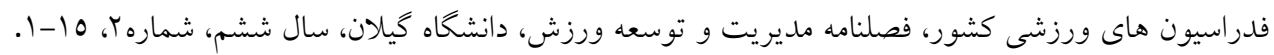

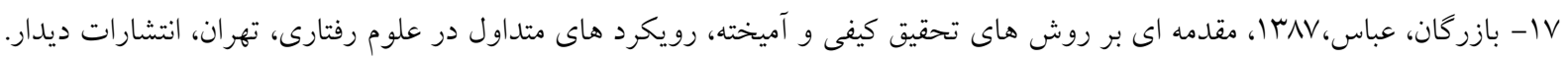

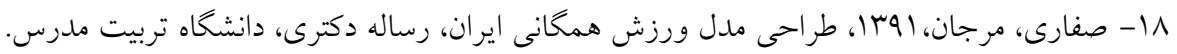

19- Cohen, Jacob, 1992, Statistical Power Analysis, Current Directions in Psychological Science, vol 1(3), 98-101

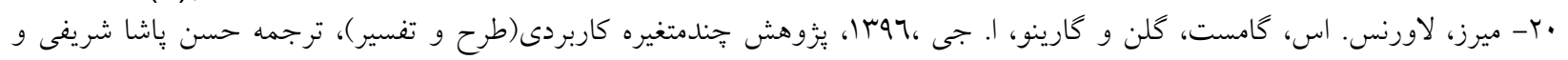
همكاران، تهران، رشد.

اب- هومن، حيدرعلى، هوسا، مدل يابى معادلات ساختارى با كاربرد نرم افزار ليزرل(با اصلاحات)، سازمان مطالعه و تدوين كتب علوم انسانى دانشخاه ها (سمت)، مركز تحقيق و توسعه علوم انسانى.

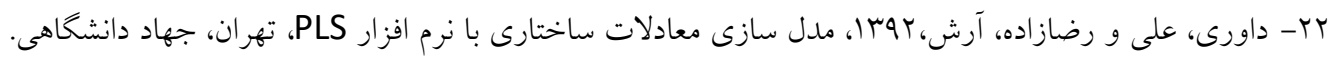

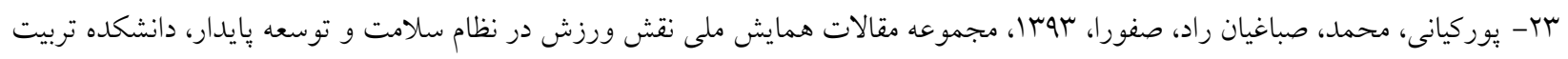
بدنى دانشگاه تهران، 0.

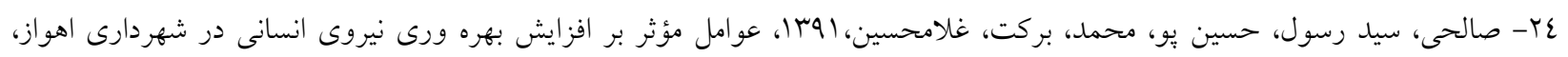

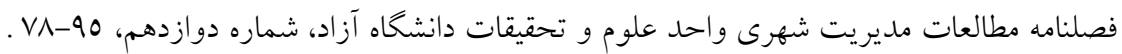

25- Bratasida, L, 2015, Green Productiyity and sustainable development.Workshop on Policy Development for Green Productivity Promotion, Taipei, Republic of China , 23-26.

جr- كيانى، ندا، رادفر، رضا ، عqجا، شناسايى و رتبهبندى عوامل موثر بر بهرهورى سازمان با استفاده از مدل ديماتل، فصلنامه مديريت بهره ورى

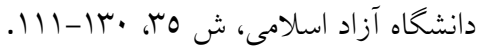

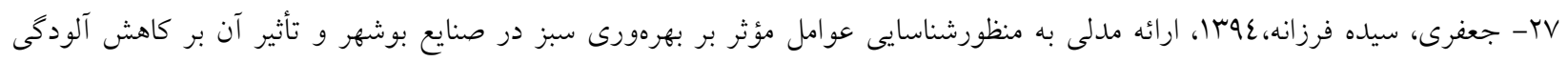

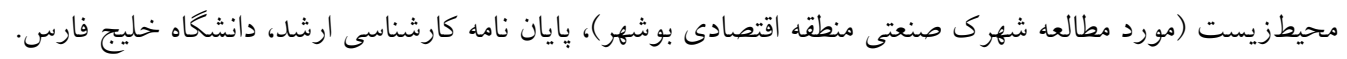

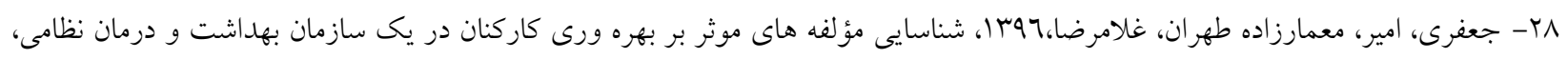

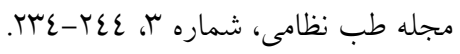

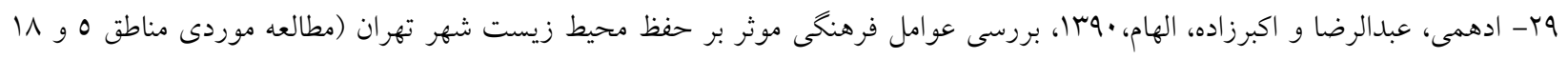
تهران)، نشريه جامعه شناسى مطالعات جوانان، شمارها، TV-Tr.

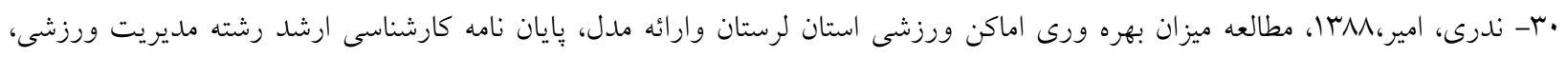
دانشخاه علامه طباطبايى.

https://jrsm.khu.ac.ir/ 


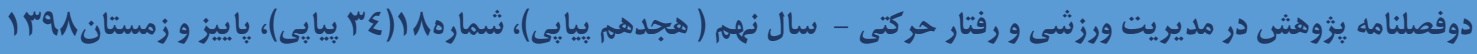

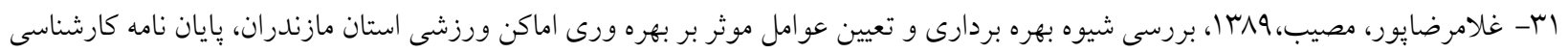

$$
\text { ارشد، موسسه آموزش عالى و غير انتفاعى شمال-آمل. }
$$

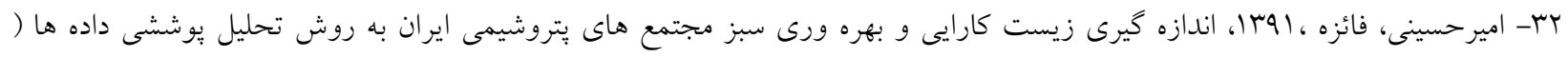
ه'DEA

33. Zhiyang .S, Jean-Philippe. B, Hervé .L, 2017, Aggregate green productivity growth in OECD's countries, International Journal of Production Economics, 189, 30-39.

https://jrsm.khu.ac.ir/ 